NBER WORKING PAPER SERIES

\title{
BANK CONCENTRATION AND FRAGILITY: IMPACT AND MECHANICS
}

\author{
Thorsten Beck \\ Asli Demirgüç-Kunt \\ Ross Levin \\ Working Paper 11500 \\ http://www.nber.org/papers/w11500
NATIONAL BUREAU OF ECONOMIC RESEARCH
1050 Massachusetts Avenue
Cambridge, MA 02138
June 2005

Beck and Demirgüç-Kunt: World Bank; Levine: Carlson School of Management at the University of Minnesota and the National Bureau of Economic Research. We received very helpful comments from John Boyd, Maria Carkovic, George Clarke, Gianni DeNicolo, Peter Garber, seminar participants at the University of Minnesota, the World Bank, and the NBER Conference on the Risks of Financial Institutions. This paper's findings, interpretations, and conclusions are entirely those of the authors and do not necessarily represent the views of the World Bank, its Executive Directors, or the countries they represent. The views expressed herein are those of the author(s) and do not necessarily reflect the views of the National Bureau of Economic Research.

(C2005 by Thorsten Beck, Asli Demirgüç-Kunt and Ross Levine. All rights reserved. Short sections of text, not to exceed two paragraphs, may be quoted without explicit permission provided that full credit, including (C) notice, is given to the source. 
Bank Concentration and Fragility: Impact and Mechanics

Thorsten Beck, Asli Demirgüç-Kunt and Ross Levine

NBER Working Paper No. 11500

July 2005

JEL No. G21, G28, L16

\begin{abstract}
Public policy debates and theoretical disputes motivate this paper's examination of (i) the relationship between bank concentration and banking system fragility and (ii) the mechanisms underlying this relationship. We find no support for the view that concentration increases the fragility of banks. Rather, banking system concentration is associated with a lower probability that the country suffers a systemic banking crisis. In terms of policies, we find that (i) regulations and institutions that facilitate competition in banking are associated with less - not more -- banking system fragility and (ii) including these policy indicators does not change the results on concentration. This suggests that concentration is a proxy for something else besides the competitive environment. Also, we do not find that official capital regulations, reserve requirements, or official prudential regulations lower crises probabilities. Finally, we present suggestive evidence that concentrated banking systems tend to have larger, better-diversified banks, which may help account for the positive link between concentration and stability.
\end{abstract}

Thorsten Beck

The World Bank

MSN MC 3-300

1818 H Street NW

Washington, DC 20433

tbeck@worldbank.org

Asli Demirgüç-Kunt

Economics Research

World Bank Group

1818 H Street NW

Washington, DC 20433

ademirguckunt@worldbank.org
Ross Levine

Department of Economics

Brown University

64 Waterman Street

Providence, RI 02912

and NBER

rlevine@csom.umn.edu

(From August 1, 2005) 


\section{Purposes \& Motivation}

Public policy debates and theoretical disputes motivate this paper's examination of the relationship between bank concentration and banking system fragility and the mechanisms underlying this relationship. The rapid consolidation of banks around the world is intensifying concerns among policymakers about bank concentration, as reflected in major reports by the Bank for International Settlements (2001), International Monetary Fund (2001), and the Group of Ten (2001). These reports note that concentration may reduce competition in and access to financial services, increase the market power and political influence of financial conglomerates, and destabilize financial systems as banks become too big to discipline and use their influence to shape banking regulations and policies. These reports also provide countervailing arguments. Consolidation may improve banking system efficiency and enhance stability as the best banks succeed, diversify, and boost franchise value. Further, some may question whether bank concentration is a reliable indicator of competition in the banking industry.

Theoretical disputes parallel these public policy deliberations. Some models yield a “concentration-stability" prediction that banking system concentration reduces fragility (Allen and Gale, 2000, 2003). In terms of mechanisms, concentration may signal less competition and hence greater market power and profits. Higher profits provide a "buffer" against adverse shocks and increase the franchise value of the bank, which reduces incentives for bankers to take excessive risk. ${ }^{1}$ Also, some hold that it is substantially easier for supervisors to monitor a few banks in a concentrated banking system than it is to monitor lots of banks in a diffuse banking

\footnotetext{
${ }^{1}$ See Boot and Greenbaum (1993), Besanko and Thakor (1993), Hellman, Murdoch, and Stiglitz (2000), and Matutes and Vives (2000). Also, Smith (1984) shows that less competition in banking leads to more stability if information about the probability distribution of depositors' liquidity needs is private and lower competition allows banking relationships to endure for longer periods. Matutes and Vives (1996), however, argue that concentration is not a consistent signal of competition, so that bank illiquidity can arise in any market structure.
} 
system, so that in equilibrium, concentrated banking systems will suffer fewer banking crises.

Some proponents of the "concentration-stability" view note that if (i) concentrated banking

systems have larger banks and (ii) larger banks hold more diversified portfolios than smaller

banks, then concentrated banking systems will tend to be more stable. ${ }^{2}$

In contrast, some models produce a "concentration-fragility" prediction, where

concentration increases fragility. Boyd and De Nicolo (2005) stress that banks in less

competitive environments charge higher interest rates to firms, which induces firms to assume

greater risk. Their model predicts that if concentration is positively associated with banks having

market power, then concentration will increase both the expected rate of return on bank assets

and the standard deviation of those returns. Also, proponents of the concentration-fragility view

disagree with the proposition that a few large banks are easier to monitor than many small banks.

If size is positively correlated with complexity, then large banks may be more difficult to

monitor than small banks, not less. Finally, some researchers argue that larger banks are

protected by implicit "too big to fail" policies that small banks do not enjoy. This protection

intensifies risk-taking incentives beyond any diversification advantages enjoyed by large banks

(Boyd and Runkle, 1992; Mishkin, 1999; O’Hara and Shaw, 1990). ${ }^{3}$ From this perspective,

\footnotetext{
${ }^{2}$ Each of these conditions is debatable. Models by Diamond (1984), Ramakrishnan and Thakor (1984), Boyd and Prescott (1986), Williamson (1986), Allen (1990), and others predict economies of scale in intermediation. As discussed by Calomiris (2000) and Calomiris and Mason (2000), research finds an inverse relationship between bank size and bank failure in the United States. However, Chong (1991) and Hughes and Mester (1998) indicate that bank consolidation tends to increase the risk of bank portfolios. Moreover, Boyd and Runkle (1993) examine 122 U.S. bank holding companies and find an inverse relationship between size and the volatility of assets returns, but not evidence that large banks fail less frequently than small banks. In contrast, De Nicolo (2000) finds a positive relationship between bank size and the probability that the bank will fail in the U.S., Japan, and several European countries. We control for bank size in our regressions, but the focus of our research is on the relationship between the concentration and fragility of national banking systems.

${ }^{3} \mathrm{~A}$ large literature indicates that implicit or explicit deposit insurance creates incentives for banks to increase risk (e.g. Merton (1977), Sharpe (1978), Flannery (1989), Kane (1989), and Chan, Greenbaum and Thakor (1992)). If this insurance were the same for banks of all sizes, these models would predict no relationship between bank size and bank fragility. Since regulators may fear potential macroeconomic consequences of large bank failures, many countries have implicit "too large to fail" policies that protect large banks more than small banks. Thus, the largest banks frequently receive a greater net insurance subsidy from the government. This subsidy may in turn increase the
} 
concentrated banking systems with a few large banks will tend to be more fragile than diffuse banking system with many small banks.

Given these conflicting theoretical predictions and policy disputes, there are surprisingly few cross-country examinations of banking system concentration and fragility. ${ }^{4}$ Although there is a growing cross-country empirical literature that uses time-series data to examine the determinants of banking crises, this research does not examine concentration (Demirgüç-Kunt and Detragiache, 1998, 1999, henceforth DD; Gonazles-Hermosillo, et al., 1997; Kaminsky and Reinhart, 1999). Although Barth et al. (2004) examine the relationship between bank regulations and crises, they do not examine bank concentration and they use pure cross-country comparisons rather than panel analyses. De Nicolo et al. (2003) find a positive relationship between banking system concentration and the fragility of the largest five banks in a country. They do not, however, examine systemic crises.

This paper (1) assesses the relationship between bank concentration and the probability that a country will suffer a "systemic" crisis and (2) provides evidence on whether particular hypothesized mechanisms linking concentration and fragility - competition, diversification, and the ease of monitoring - account for the identified relationship between concentration and stability. We focus on these three mechanisms because of their prominence in policy and academic discussions.

To investigate systemic crises, we use annual data on 69 countries over the period 19801997. While no single, unambiguous definition of a systemic crisis exists, we use the DD (2002)

risk-taking incentives of the larger banks more than smaller banks. For an analysis of the corporate governance of banks, see Macey and O'Hara (2003). Note, however that even in the absence of deposit insurance, banks are prone to excessive risk-taking due to limited liability for their equity holders and to their high leverage (Stiglitz, 1972).

${ }^{4}$ For the United States, Keeley (1990) provides evidence that increased competition following the relaxation of state branching restrictions in the 1980s increased the risk of large banks. However, Jayaratne and Strahan (1998) find that deregulation in the 1980s lowered loan losses, and Dick (2003) finds higher loan loss provisions following deregulation in the 1990s. 
classification and confirm the results with other definitions. DD (2002) consider a country to be in a systemic crisis if (i) authorities use emergency measures, such as bank holidays, deposit freezes, blanket guarantees, etc., to assist the banking industry, (ii) countries undertake large scale nationalizations of banks, (iii) non-performing loans top ten percent of total banking assets, or (iv) the fiscal costs of rescue operations exceed two percent of Gross Domestic Product (GDP). Using logit regressions, we analyze the association between banking system concentration and the probability that a country experiences a systemic crisis. In the analyses we condition on many country characteristics, including bank supervisory and regulatory practices, institutional development, and macroeconomic controls, such as the level of economic development, economic growth, inflation, interest rates, terms of trade changes, and credit growth.

The results are inconsistent with the concentration-fragility view. We do not find a positive relationship between banking system concentration and the likelihood that the country suffers a systemic crisis. Using different conditioning information sets, different sample periods, different definitions of crises, and different measures of concentration, we never find a significant, positive link between concentration and crises. Thus, our analyses lend no support to the view that concentration increases the fragility of banks.

Rather, the findings are broadly consistent with the concentration-stability view. Concentration enters the crises regressions negatively and significantly across a wide array of specifications. Thus, although we emphasize numerous qualifications below, the data consistently indicate a positive relationship between national bank concentration and banking system stability. 
Furthermore, we provide exploratory evidence on the potential mechanisms competition, diversification, and ease of monitoring -- underlying the positive relationship between concentration and stability. First, to assess whether concentration proxies for competition, we include bank regulatory indicators and measures of national institutional development. More specifically, we control for national policies toward bank entry, bank activities, bank ownership as well as several indicators of national institutions that affect competition. If (i) these variables measure the competitive environment in banking and (ii) concentration proxies for competition, then including these variables should eliminate the significance of concentration in the fragility regressions. Moreover, these assessments provide independently valuable information on the linkages between banking system fragility and bank regulations. Second, to assess whether concentration proxies for diversification or ease of monitoring, we include numerous indicators that attempt to proxy for these mechanisms. For diversification, we control for (a) the size of the economy, which may correlate positively with the ability of banks to diversify domestically, (b) restrictions on making loans abroad, which may correlate negatively with the ability of banks to diversify internationally, and (c) mean bank size, which some argue is positively correlated with diversification. For ease of monitoring, we control for (a) the number of banks, (b) regulatory restrictions on banks ability to engage in nonlending services since the complexity of banks may hinder monitoring, (c) mean bank size since larger banks may be more complex than smaller banks, (d) capital regulatory requirements, deposit insurance, and other prudential regulations, and (e) the average cash flow rights of the controlling owner, if any, of the largest, listed banks in the country, which may reflect the incentives of the largest owner to govern the bank effectively. Again, if including these variables eliminates the relationship between concentration and fragility, then this provides 
circumstantial evidence that concentration acts as a proxy for diversification or the cost of monitoring banks.

In terms of regulatory policies and institutional development, we find that (1) fewer regulatory restrictions on banks - lower barriers to bank entry, fewer restrictions on bank activities, and fewer impediments to bank operations in general - reduce banking system fragility and (2) countries with national institutions that foster competition have lower banking system fragility. Thus, policies and institutions that facilitate competition in banking are associated with less - not more -- banking system fragility. Furthermore, capital requirements, reserve requirements, and prudential regulations do not affect the results on concentration and, interestingly, do not reduce the likelihood of suffering a systemic crisis. Regarding specific mechanisms associated with the concentration-stability view, the findings that (i) banking system concentration is associated with lower fragility and (ii) policies that foster competition are associated with lower fragility suggest that concentration is proxying for something else besides a lack of competition.

In terms of diversification, we find some support for the view that one of the mechanisms underlying the negative relationship between concentration and banking system fragility is that concentrated banking systems tend to have larger, better-diversified banks. While recognizing that the measures of diversification are both indirect and potentially imprecise, we find that controlling for proxies of diversification substantially reduces the ties between concentration and crises. More specifically, we find that (i) controlling for the size of the domestic economy eliminates the connection between concentration and systemic crises, (ii) controlling for the mean size of banks weakens the link between concentration and crises, and (iii) controlling for mean bank size and restrictions on foreign loans eliminates the negative relationship between 
banking system concentration and the probability of suffering a systemic crisis. The results are consistent with arguments that countries with, on average, larger banks tend to have a lower likelihood of suffering a systemic crisis and inconsistent with the view that large banks distort public policies in a manner that increases banking system fragility.

In contrast, we find no support for any of the views suggesting that concentration is a proxy for the degree of difficulty in monitoring banks. When controlling for the number of banks, or regulatory restrictions on banks, or capital requirements, or prudential regulations, or the cash flow rights of the bank's controlling owner (if any), this does not change the finding of a negative relationship between concentration and crises. In sum, we did not find much support that a distinguishing characteristic of concentrated banking systems is that they are easier to monitor than more diffuse systems.

The analyses in this paper are subject to considerable qualifications and interpretational limitations.

First, as our own results emphasize, concentration is not necessarily a reliable indicator of competition (Tirole, 1988; Sutton, 1991, 1998). Mergers and acquisitions that increase concentration could reflect competition, not the absence of competition. A country with a few banks in a contestable market may be more competitive than a country with lots of banks in segmented monopolies. This does not invalidate this paper's usefulness. Around the world, policymakers, in forming bank regulations, and courts, in assessing anti-trust challenges to bank consolidation, use banking system concentration as a signal. Toward this end, our work suggests that (i) banking system concentration is not associated with greater bank instability; rather, it is associated with less fragility and (ii) policies and regulations that ease competition lower banking system fragility. 
Second, although we use different measures of banking system crises, any examination of systemic crises is constrained by the difficulty in defining and dating a "systemic" crisis. Thus, we interpret these results cautiously and trust that this information is one useful input into assessing the linkages between the market structure of the banking industry, bank regulations, and banking system fragility. Future research that examines the interactions among concentration, bank regulations, and bank fragility at the microeconomic level will provide a very valuable addition to the crises analyses that we provide.

Third, the absence of time-series data on bank regulations lowers confidence in the finding that regulatory impediments to bank competition increase fragility. The regulatory indicators are measured toward the end of the sample period, so that these indicators are sometimes measured after the crisis. This data limitation is difficult to correct because it is only very recently that detailed data have been collected on bank regulations around the world (Barth, et al. (2001a,b, 2004, 2005). More importantly for the purposes of this paper, this timing issue does not affect the core finding supporting the concentration-stability view as these results hold when including or excluding the regulatory indicators. Furthermore, sensitivity checks suggest that regulatory impediments to competition did not grow after systemic crises, so that reverse causality does not seem to drive the results.

Finally, our exploratory evidence that (i) supports the view that concentrated banking systems tend to have larger, better-diversified banks and (ii) contradicts the view that concentrated banking systems with a few large banks are easier to monitor is just that, exploratory. The measures that we use are highly imperfect measures of diversification and the ease of monitoring. Nevertheless, when including imperfect indicators of diversification, this reduces the significance of concentration in the fragility regressions, suggesting that 
concentration may proxy for banking systems with larger better-diversified banks. Given the natural skepticism about our proxies, however, considerably more evidence is required before one can draw confident conclusions about the mechanisms underlying the negative relationship between concentration and fragility.

The remainder of the paper is organized as follows. Section II analyzes the relationship between banking system concentration and systemic crises. Section III provides additional information on the mechanisms explaining the positive relationship between concentration and banking system stability. Section IV briefly lists conclusions. 


\section{Does Bank Concentration Enhance the Risk of Systemic Failure?}

In this section, we examine the impact of national bank concentration on the likelihood of a country suffering a systemic banking crisis. Using data on 69 countries over the period 19801997, we assess the connection between banking system concentration and the incidence of systemic banking failures. ${ }^{5}$ To assess the robustness of our analyses, we (i) use a range of different measures of bank concentration and crises, (ii) control for an array of country characteristics, (iii) use different estimation procedures and samples of countries, and (iv) allow for potential nonlinearities in the relationship between concentration and crises. After describing data and methodology in the first two subsections, we present the regression results.

\section{A. Data}

\section{II.A.1. Data: Crises and concentration}

Following Lindgren, Garcia and Saal (1996), Caprio and Klingebiel (1999), and Demirguc-Kunt and Detragiache (DD, 2002), we identify and date episodes of banking sector distress by using information on individual bank failures and reports by national supervisory agencies. Then, these episodes of distress are classified as systemic (i) if emergency measures were taken to assist the banking system (such as bank holidays, deposit freezes, blanket guarantees to depositors or other bank creditors), or (ii) if large-scale nationalizations took place, or (iii) if non-performing assets reached at least 10 percent of total assets at the peak of the crisis, or (iv) if the cost of the rescue operations was at least 2 percent of GDP. In sum, our sample of 69 countries contains 47 crisis episodes. Table 1 lists this information.

\footnotetext{
${ }^{5}$ Demirgüç-Kunt, et al. (2004) investigate the impact of bank concentration on bank net interest margins, but they do not examine bank fragility.
} 
Crisis is a dummy variable that equals one if the country is going through a systemic crisis, and zero if it is not. We experiment with different ways of dating and defining crises. ${ }^{6}$ First, since crises run for multiple years and since crises may influence concentration and other explanatory variables, implying reverse causality, most of the regressions reported in the tables exclude observations classified as crises after the initial year of the crisis. That is, we only include the initial year of a multi-year crisis. We do include the years after a multi-year crisis is over, which are non-crisis observations. ${ }^{7}$ If the country suffers a second crisis, this is included as well. Second, we also conducted the analyses when including crisis observations following the initial year of a multi-year banking crisis. The results are robust to including these years and classifying them as either crisis observations or non-crisis observations. Thus, the results are not sensitive to the classification of the crisis years following the initial year of multi-year crisis. Again, once each crisis is over, we include the non-crisis years that follow a multi-year crisis in all of the specifications. Third, this paper's findings are robust to changing the definition of a crisis to also include borderline crises as defined by Caprio and Klingebiel (1999). Specifically, borderline cases do not meet the definition of a systemic crisis described above and instead include cases where a large bank fails. We do not believe it is appropriate to include borderline cases because we are assessing the impact of banking system concentration on systemic banking crises, not the failure of a large bank. In sum, while recognizing that there is no single, unanimous definition of a systemic banking crisis, the primary goal of this section is to provide a cross-country, time-series assessment of the relationship between national bank concentration

\footnotetext{
${ }^{6}$ Clearly, there may be disagreements about the dating of major crises. For example, the database we are using classifies the United States as having a crisis from 1980-1992 and many may dispute this dating. Nevertheless, we use different dating conventions and we use different sub-samples to reduce fears that dating problems drive the results.

${ }^{7}$ The results also hold when dropping all post-crisis years for each country experiencing a crisis.
} 
and crises. The identified relationship is robust to using these different definitions of a systemic crisis.

Concentration equals the share of total banking system assets held by the three largest banks. The data are from the Bankscope database. Since the sample of banks covered in Bankscope increased over the sample period, changes in the concentration measure could reflect changes in coverage. To reduce biases stemming from the coverage problem, we average the concentration measure over the period 1988-1997. As reported in Tables 1 and 2, most countries have concentrated banking systems with a sample mean of 72 percent. Still, there is wide crosscountry variation in the sample, with concentration levels ranging from less than 20 percent for the U.S. to 100 percent for many African countries. Simple correlations show a significant negative relationship between the crisis dummy and bank concentration.

In robustness tests, we consider a number of different concentration measures. This paper's results hold when using (i) annual concentration values, (ii) concentration from Bankscope measured at the beginning of the sample period (1988), and (iii) a measure of concentration based on the Barth et al (2004) survey of bank supervisory agencies regarding deposits in banks. ${ }^{8}$ Moreover, by confirming our results using the initial level of concentration at the start of the sample period, we reduce reverse causality concerns. Unfortunately, using initial values cuts the number of observations in half. Thus, we focus on the data averaged over the entire period.

\footnotetext{
${ }^{8}$ This alternative measure of concentration is from the Barth et al (2004) survey database, which defines bank concentration as the share of deposits of the largest five banks. The correlation between the concentration measures calculated from Bankscope data and from Barth et al. is 52\%, and is significant at the $1 \%$-level.
} 


\section{II.A.2. Data: Core Control variables}

To investigate the relationship between systemic banking crises and banking system concentration, we condition on an assortment of macroeconomic and regulatory factors that may also influence banking system fragility.

We start with the explanatory variables from DD's (2002) examination of the determinants of banking system crises. DD (2002) include four contemporary explanatory variables to control for macroeconomic factors that may affect the quality of bank assets and bank profitability: (i) national economic growth (Real GDP Growth), (ii) changes in the external terms of trade (Terms of Trade Change), (iii) the rate of inflation (Inflation), and (iv) the short-term real interest rate (Real Interest Rate). DD (2002) include two variables to control for international forces influencing bank vulnerability: (i) the rate of exchange rate depreciation (Depreciation) and (ii) the ratio of M2 to foreign exchange reserves

(M2/Reserves). Since rapid credit growth may signal an asset price bubble, DD (2002) include lagged credit growth (Credit Growth $\mathbf{t}_{\mathbf{t}-2}$ ). To condition on the overall level of economic development, DD (2002) also include the level of real per capita GDP (GDP per capita). In robustness tests, we also include DD's (2002) measure of deposit insurance generosity (Moral Hazard). To build an aggregate index of moral hazard, DD (2003) estimate the first principal component of various deposit insurance design features. Specifically, they use coinsurance, coverage of foreign currency and inter-bank deposits, type of funding, source of funding, management, membership, and the level of explicit coverage to create this aggregate index that increases with the generosity of the deposit insurance regime. The index varies over time since different countries adopted deposit insurance or revised its design features at different points in time. 
Simple correlations in Table 2 suggest that banking crises are more likely in countries with less concentrated banking systems, higher levels of inflation and exchange rate depreciation and less likely in growing countries with higher GDP per capita and higher real interest rates. Crises are more likely in countries with more generous deposit insurance.

\section{II.A.3. Data: Bank Regulation and Supervision Control variables}

We augment the benchmark specification from DD (2002) by including measures of bank regulation and supervision from Barth et al., (2001a,b, 2004). These data on bank supervision and regulation around the world were collected through surveys of government officials from over 100 countries in 1999. This is a problem because the crises regressions are run over the period 1980-1997. Thus, the regulatory indicators are measured after the dependent variable. Besides the fact that no other dataset has the level of cross-country detail on bank regulations, we offer three additional defenses for using these data in the crisis regressions despite the time problem. First, Barth et al., (2001a) show that the regulatory restrictions on bank activities did not change much following systemic crises. Moreover, in the few cases when they did change, there was a change toward fewer regulatory restrictions. Thus, the timing of the Barth et al. (2001a) data actually biases the results against finding a positive relationship between regulatory restrictions on bank activities and the likelihood of suffering a systemic crisis. Second, Carkovic and Levine (2002) show that the bank regulations that compose the Barth et al. (2001a) survey have remained virtually unchanged in Chile during the decade of the 1990s. Third, Barth, et al.'s (2005) follow-up survey indicates that there have been remarkably few substantive changes in bank regulatory regimes since the initial survey in 1999, which advertises the stability of bank supervisory and regulatory policies. Nevertheless, timing issues are an important constraint on 
our ability to draw confident conclusions on the market power, diversification, and easier monitoring explanations of why concentration is associated with more stable banking systems.

We include bank regulation indicators to accomplish three objectives. First, controlling for differences in national policies provides a simple robustness test of the relationship between concentration and crises. Second, controlling for regulations provides additional information on the concentration-fragility relationship. If concentration is proxying for regulations that impede competition, then controlling for the regulatory environment will drive out the significance of concentration in the crisis regression. Finally, examining the relationship between bank regulations and banking system stability is independently valuable since countries may implement regulations to promote banking system stability. The timing problem primarily, though not necessarily exclusively, affects this last motivation for including the regulatory controls: The fact that regulations are measured after crises reduces the confidence we have in the results on regulations.

Fraction of Entry Denied equals the number of entry applications denied as a fraction of the number of applications received from domestic and foreign entities, which is a measure of entry restrictions in banking and thus the contestability of the market. If entry restrictions only increase bank profits, this would be associated with a lower rate of fragility. If however, entry restrictions induce inefficiencies in the banking market, then they could lead to greater fragility.

Activity Restrictions is an index of regulatory restrictions on bank activities. This includes information on regulation regarding bank activities in the securities, insurance, real estate markets, and banks owning nonfinancial firms. For each of these four categories of bank activities, each country is given a score of one through four depending on the degree to which regulations restrict bank activity in each area: (1) unrestricted, (2) permitted, (3) restricted, or (4) 
prohibited. The aggregate indicator has therefore a range from four to 16 , with higher numbers indicating more restrictions on bank activities. If these activity restrictions keep banks from entering risky lines of business, then Activity Restrictions will tend to reduce the probability of crises. If, however, regulatory restrictions on bank activities prevent firms from diversifying risks, then higher values of Activity Restrictions will tend to increase the probability of suffering a systemic crisis.

Required Reserves equals the ratio of bank assets that regulators require banks to hold as reserves. Banking systems with higher ratios of required reserves may be more stable since they would have a greater buffer to absorb liquidity shocks. However, greater required reserves are also a tax on the banking system, which may lower profits and raise fragility.

Capital Regulatory Index is a summary measure of each country's capital stringency requirements and taken from Barth et al (2004). To the extent that book capital is an accurate measure of bank solvency we expect better capitalized banks to be less fragile. Also, capital regulations are a focus of Basel agreements to reduce systemic risk. Thus, including an index of national capital regulations will provide information on whether cross-country differences in one of the three "pillars" of the Basel II Accord on prudential bank supervision and regulation actually explain differences in banking system fragility. Problematically, however, Barth et al (2005) stress that Basel's success and the lack of historical data on capital regulations make it difficult to assess the impact of capital regulations. Specifically, because Basel has successfully harmonized capital regulations over the past decade, there may be insufficient cross-country variation in the Capital Regulatory Index to explain systemic crises.

Official Supervisory Power is an index of the power of the commercial bank supervisory agency to monitor and discipline banks (Barth, et al., 2004). It includes information 
on the legal power of the supervisory authority to (i) meet with, demand information from, and impose penalties on auditors, (ii) force a bank to change its internal organizational structure, managers, directors, etc. (iii) oblige the bank to provision against potential bad loans, suspend dividends, bonuses, management fees, and to supersede the rights of shareholders, and (iv) intervene a bank and/or declare a bank insolvent. The Appendix provides a more detailed definition of Official Supervisory Power. An emphasis of the Basel II accord on prudential supervision and regulation is to strengthen official monitoring of banks. We use this indicator of the power of the supervisory authority to assess the robustness of the results on concentration and to examine the relationship between Official Supervisory Power and the probability that a country suffers a systemic crisis.

\section{II.A.4. Data: Bank Ownership Control variables}

Next, we also control for ownership.

State ownership equals the percentage of banking system assets controlled by banks that are 50 percent or more government owned, which is taken from the Barth et al (2001) database. ${ }^{9}$ If government owned banks enjoy greater government support than private banks, then banking systems with a larger share of public banks may experience fewer banks runs and fewer (overt) banking crises. However, inefficiencies in public banks may also make them more fragile as argued by Caprio and Martinez-Peria (2000). While providing evidence on the relationship between ownership and crises, we use State Ownership as a control variable to test the

\footnotetext{
${ }^{9}$ As a robustness check, we employ a different measure of state-ownership from La Porta et al. (2002), which equals the percentage of government ownership (voting rights) of the assets of the ten largest banks in each country where ownership of each bank is weighted by the assets of that bank. Thus, the La Porta et al. (2002) measure does not define bank ownership in terms of voting rights greater than 50 percent. We get the same results with both measures.
} 
robustness of the results between concentration and crises. There is not a significant correlation between State Ownership and crises.

Foreign Ownership equals the percentage of the banking system's assets in banks that are 50 percent or more foreign owned, which is also taken from the Barth et al., (2001) database. Foreign banks may bring better banking practices that improve the operation and safety of the banking system (Claessens, et al., 2001). On the other hand, greater openness to foreign banks could intensify competition, reduce profits, and hurt stability. Thus, it is an empirical question as to whether, on net, foreign bank ownership stabilizes or destabilizes a banking system. Again, our goal is to assess the robustness of the relationship between concentration and crises, not to explore fully the impact of foreign banks on the operation of domestic financial system. The simple correlation between Foreign Ownership and crises is insignificant.

\section{II.A.5. Data: Openness, Competition, Institutional Control Variables}

Finally, we include additional control variables for the general openness, competitiveness, and institutional development of the banking sector in particular and the economy more generally. There is overlap between some of these general indexes and the individual regulatory and ownership variables defined above. Also, there is overlap among these general indicators. Thus, we note these overlaps in defining the variables and do not include them simultaneously in the regressions below.

Banking Freedom is an indicator of the relative openness of the banking system. We obtain these data from the Heritage Foundation and use an average over the period 1995-97. It is a composite index of the barriers foreign banks and financial services firms face in conducting banking operations, how difficult it is to open domestic banks and other financial services firms, 
how heavily regulated the financial system is, the presence of state-owned banks, whether the government influences allocation of credit, and whether banks are restricted from providing insurance and securities market services to clients. Higher values indicate fewer restrictions on banking freedoms. This aggregate Banking Freedom indicator also uses information from the regulatory restrictions, entry restrictions, and ownership indicators discussed above. We include this for two reasons. First, debate exists on the impact of official restrictions on bank operations. On the one hand, fewer official impediments to bank operations and entry could stimulate efficiency and diversification that promotes stability. On the other hand, greater banking freedom could induce destabilizing competition. We provide information on this debate. Second, official impediments to bank freedom could influence both concentration and fragility. Since our goal is to assess the independent link between concentration and crises, we test the robustness of the findings to controlling for banking freedom.

Economic Freedom is an indicator of how a country's policies rank in terms of providing economic freedoms. It is a composite of ten indicators ranking policies in the areas of trade, government finances, government interventions, monetary policy, capital flows and foreign investment, banking and finance, wages and prices, property rights, regulation, and black market activity. We obtain these data from the Heritage Foundation and use an average over the period 1995-97. Higher scores indicate polices more conducive to competition and economic freedom. Also, Banking Freedom is a subcomponent of Economic Freedom, which includes information on economic freedom beyond the banking industry. To the extent freedoms allow banks to improve efficiency and to engage in different activities and diversify their risks, we expect increased level of freedoms to reduce fragility. However, it is also true that greater freedoms allow banks to undertake greater risks, particularly if the underlying institutional 
environment and existing regulations and supervision distort risk-taking incentives. Thus, overall greater freedom may also lead to greater bank fragility. Thus, we (a) examine the relationship between economic freedom and crises and (b) assess the strength of the relationship between concentration and crises conditional on overall economic freedom.

KKZ_Composite is an index of the overall level of institutional development constructed by Kaufman, Kraay and Zoido-Lobaton (1999). The underlying indicators are voice and accountability, government effectiveness, political stability, regulatory quality, rule of law, and control of corruption. This index is available for 1998. We expect better institutions to lead to reduced bank fragility, controlling for all other factors. Simple correlations indicate that the crisis dummy is negatively and significantly correlated with the two freedom indicators and the institutions variable. Countries with better institutions also tend to have more competitive banking systems with fewer regulatory restrictions. Thus, it is independently valuable to examine the relationship between institutional development and banking system stability. At the same time, we use KKZ_Composite to gauge the strength of the independent relationship between concentration and crises.

\section{II.B. Methodology}

Methodologically, to estimate the crisis model, we follow Cole and Gunther (1995), Gonzalez-Hermosillo et al. (1997), Demirguc-Kunt (1989), and DD $(1998,2002)$ and use a logit probability model with standard errors that are robust to heteroskedasticity. Specifically, we estimate the probability that a systemic crisis will occur at a particular time in a particular country, assuming that this probability is a function of explanatory variables $(\mathrm{X}(\mathrm{i}, \mathrm{t}))$. Let $\mathrm{P}(\mathrm{i}, \mathrm{t})$ denote a dummy variable that takes the value of one when a banking crisis occurs in country $i$ 
and time $t$ and a value of zero otherwise. $\beta$ is a vector of $n$ unknown coefficients and $F(\beta N X(i, t))$ is the cumulative probability distribution function evaluated at $\beta \mathrm{NX}(\mathrm{i}, \mathrm{t})$. Then, the loglikelihood function of the model is:

$$
\operatorname{Ln} \mathrm{L}=\sum_{\mathrm{t}=1 \ldots \mathrm{T}} \sum_{\mathrm{i}=1 \ldots \mathrm{n}}\{\mathrm{P}(\mathrm{i}, \mathrm{t}) \ln [\mathrm{F}(\beta \mathrm{NX}(\mathrm{i}, \mathrm{t}))]+(1-\mathrm{P}(\mathrm{i}, \mathrm{t})) \ln [1-\mathrm{F}(\beta \mathrm{NX}(\mathrm{i}, \mathrm{t}))]\}
$$

We also conducted robustness tests using alternative estimation procedures. First, this core specification allows for heteroskedasticity but assumes that the errors are independent. We confirm the results, however, when allowing for clustering of the errors within countries, which requires that the error terms are independent across countries but not within countries. Second, the results hold when estimating a logit model with random country effects.

\section{II.C. $\underline{\text { Results }}$}

The paper finds that crises are less likely in more concentrated banking systems using different measures of concentration and conditioning on different country characteristics. As shown in Table 3, Concentration always enters with a negative and significant coefficient. Regression 1 presents our baseline specification, where we exclude observations classified as crises after the first year of a multi-year banking crisis. Regressions 2 and 3 include crisis observations after the initial crisis year. In column 2, crisis observations following the initial year of a multi-year crisis are classified as crises. ${ }^{10}$ In column 3 , crisis observations after the

\footnotetext{
${ }^{10}$ This explains the entry of 202 crises in column 2 of Table 3 . When we include all of the years of each multi-year banking crisis, this adds an additional 155 crisis observations to the number reported in regressions 1 and 3 .
} 
initial year of a multi-year crisis are classified as non-crisis observations. ${ }^{11}$ In all three regressions, Concentration enters negatively and significantly.

The negative relationship between concentration and crises is robust to alternative specifications and to controlling for reverse causality. If systemic crises reduce concentration, then it would be inappropriate to interpret our early results as implying that concentration reduces banking system fragility. Thus, in regression 4 , we use the value of banking system concentration measured at the beginning of the sample period instead of concentration averaged over the period. Even when using initial concentration, however, we continue to find a negative relationship between concentration and crises. Regression 5 shows that the results do not depend on including or excluding Real GDP per capita. Regression 6 assesses whether the results change if the country is a G10 country. We see that country membership in the G10 does not alter the results on concentration. Further, the insignificant interaction between concentration and membership in G10 indicates that the relationship between concentration and systemic banking fragility does not vary between the G10 countries and the remainder of the sample.

Among the control variables in Table 3, annual Real GDP growth enters negatively and significantly throughout. This suggests that macroeconomic success reduces the likelihood of suffering a crisis. Or, to phrase this differently, recessions increase banking system fragility. The estimates also indicate that Real interest rate enters positively, which confirms earlier research (Demirguc-Kunt and Detragiache, 1999).

Furthermore, the economic impact of banking system concentration on the likelihood of a country suffering a systemic crisis is large. We evaluate the marginal impact of concentration on the probability of crisis at the mean values for all variables using regression 1 from Table 3 . The

\footnotetext{
${ }^{11}$ In all three specifications, we include observations after the crisis is over. Thus, we include the switch from crisis to the non-crisis state.
} 
estimates indicate that a one standard deviation increase in concentration leads to a decrease in crisis probability of one percent. Since crisis probabilities at any point in time are quite low, with a mean value of four percent, this is a substantial reduction. We have recalculated the economic impact of a marginal increase in bank concentration when using a sample that includes the year after the initial year of the crisis. Using this larger sample, we find an even larger economic impact of concentration on crises than in the core regression presented in Table 3.

This paper's findings hold when allowing for a potential nonlinear relationship between concentration and crises. First, we added a simple quadratic term and found no evidence of a nonlinear relationship. Next, we estimated piece-wise regressions, where concentration was broken into (a) quintiles and then (b) deciles. The results indicate that the stabilizing effect of concentration becomes significant after the first quintile (second decile), where the quintile and decile analyses identify consistent cut-offs. The data indicate that there is a statistically significant, negative relationship between concentration and banking system fragility for levels of concentration above 35 percent and the marginal impact of a change in concentration does not vary significantly beyond this 35 percent cut-off. This cut-off is low, considering that the sample mean value of national banking system concentration is 72 percent. There is never a positive relationship between concentration and fragility. Third, we examine whether concentration has different effects in different institutional settings by interacting concentration and our measures of institutional development (Economic Freedom and KKZ_composite). Again, this did not change the result of a negative relationship between bank concentration and the probability of suffering a systemic crisis.

The negative relationship between crises and concentration also holds when using different samples of countries. Specifically, we excluded all countries with populations less than 
1 million, less than 10 million, and less than 20 million, respectively. The coefficient on concentration remains negative and significant across these three different samples of countries. Next, we excluded all Sub-Saharan African countries since they tend to have very high bank concentration ratios and we eliminated the G-10 countries because their high level of institutional development may not be captured appropriately with the control variables. Again, these two different samples yield the same results. Finally, we excluded a few country-year data points where the data seem to be mis-measured because the values are extraordinarily different from the country's average value over the sample. ${ }^{12}$ The results do not change.

In sum, these results are consistent with the concentration-stability theory's argument that banking systems characterized by a few, large banks are more stable than less concentrated banking markets. There is certainly no evidence that banking system concentration increases banking sector fragility. Furthermore, the inverse relationship between banking system concentration and the likelihood of suffering a systemic crisis holds when allowing for possible nonlinear links between concentration and fragility and when using different samples of countries. Next, we assess the robustness of these results to conditioning on additional country specific traits.

\section{II.D. Additional Sensitivity Tests and Discussion \\ II.D.1. Additional Country Level Controls}

In Table 4, we confirm the findings on the relationship between banking sector concentration and systemic crises when controlling for (i) moral hazard associated with deposit insurance, (ii) different bank regulations, (iii) the ownership of banks, and (iv) general indicators

\footnotetext{
${ }^{12}$ Specifically, we eliminate Ivory Coast (1993) because their M2/reserves values are very different for that year. Similarly, in these outlier tests, we exclude Peru (1991) because its inflation and real interest rate values are so different from other years.
} 
of banking freedom, economic freedom, and institutional development. The results hold when controlling for Moral Hazard, Fraction of Entry Applications Denied, Activity Restrictions, Official Supervisory Power, Required Reserves, and the Capital Regulatory Index (regressions 1 -6). The significance level on Concentration falls to ten percent level when including Fraction of Entry Applications Denied, but data limitations on Fraction of Entry Applications Denied cuts the sample from 989 to 583 observations. Furthermore, Concentration remains negatively associated with crises at the one percent significance level when controlling for state or foreign ownership of banks (regressions 7 and 8). In terms of broad measures such as Banking freedom or general indictors of Economic freedom and institutional development (KKZ_composite), Concentration continues to enter the crisis regress negatively and significantly at the one percent level (regression 9-11). The regressions in Table 4 do not include GDP per capita because (i) the regulatory/institutional variables are highly correlated with the level of development and (ii) GDP per capita is often used to proxy for institutional development. However, including GDP per capita in Table 4 does not change the conclusions on concentration.

Beyond Concentration, the Table 4 results indicate that tighter entry restrictions and more severe regulatory restrictions on bank activities boost bank fragility. These are consistent with the results obtained by Barth et al. (2004), who examine the impact of entry restrictions and regulatory restrictions on bank activities on crises in a purely cross-country investigation that does not control for bank concentration. A higher fraction of entry applications denied - a proxy for tighter entry regulations - leads to higher levels of fragility in the banking system. This is consistent with the argument that restricted entry reduces the efficiency of the banking system, also making it more vulnerable to external shocks. Similarly, we find that restrictions on bank activities increase crisis probabilities. This result indicates that overall these restrictions prevent 
banks from diversifying outside their traditional business, reducing their ability to reduce the riskiness of their portfolios.

Overall, the results do not provide support for Basel II's emphasis on capital regulations and more stringent regulations. We do not find that stricter capital regulations or greater official supervisory power lowers the probability that a country will suffer a systemic crisis. While it is natural and appropriate to question these results because of the timing issues emphasized above, we are unaware of cross-country research that finds that banking system stability is enhanced by countries adopting official supervisory and regulatory regimes that impose stricter capital regulations or more stringent prudential regulations. Indeed, a growing body of evidence suggests that strengthening official supervisory power can actually increase corruption in lending and reduce banking system efficiency (Barth et al., 2005; Beck, et al., 2004; Demirguc-Kunt, Laeven, and Levine, 2004). Finally, confirming earlier research, we also see that state ownership is associated with greater fragility, albeit significant only at ten percent (Caprio and MartinezPeria, 2000). 
Furthermore, the results in Table 4 suggest that openness, competition, and institutional development foster greater banking system stability. Countries with greater freedoms in banking (Banking Freedom) and generally more competitive economic systems (Economic Freedom) are less likely to experience banking crises (regressions 9 and 10). This finding suggests that concentration is not simply proxying for the degree of competition in the banking industry. Better institutional environment is also associated with a lower probability of systemic crisis (regression 11). The evidence is consistent with theories that emphasize the stabilizing effects of openness and competition, but inconsistent with the many models that stress the destabilizing effects from competition. ${ }^{13}$

\section{II.D.2. Costs of Banking Crises}

We also assessed whether countries with concentrated banking systems have bigger, more costly banking crises. If (i) concentrated banking systems are more likely to have too-bigto-fail policies and (ii) too-big-to-fail policies induce greater risk-taking and (iii) too-big-too fail policies can operate for only some fixed period of time, then this suggests that crises will be larger, though less frequent, in concentrated banking systems. If this were the case, then our findings that (a) concentration is associated with a lower probability of suffering a systemic crisis and (b) concentration is associated with greater bank-level stability may provide a misleading impression of the concentration-stability relationship.

Thus, in Table 5, we examine the relationship between banking system concentration and the costs of banking crises. To include countries that suffered no crises in the sample, we use a

\footnotetext{
${ }^{13}$ Boyd and De Nicolo (2005) stress that competition exerts a stabilizing impact on banks because more competitive banks charge lower interest rates to firms and these lower rates reduce the likelihood of default. This prediction is consistent with our results. However, Boyd and De Nicolo (2004) use bank concentration as an indicator of bank competition. Thus, they stress that concentration will exert a destabilizing impact on banks, which is inconsistent with our results.
} 
Tobit model, where zero implies that the country did not experience a banking crisis. We use three different measures of banking crisis costs. The first two measures are from Klingebiel and Honohan (2003). The last is the Boyd and Smith (2005) measure of the cost of the banking crises.

As shown in Table 5, we find no evidence for the contention that more concentrated banking systems have more costly crises. Concentration does not enter significantly at the five percent level in any of the regression. It enters with a negative coefficient across the different cost measures. Given the lack of a robust relationship, however, we do not draw the conclusion that concentration reduces both the likelihood and the size of crises.

\section{Why is Concentration Stabilizing? Additional Evidence from Crisis Data}

Although the finding of a negative relationship between banking system concentration and the likelihood of suffering a systemic crisis is consistent with the concentration-stability view (Tables 3 and 4), the results do not distinguish among possible explanations of this finding. Why is concentration stabilizing? This section explores the validity of different explanations for why bank concentration lowers banking system fragility.

\section{A. Is it market power and bank profits?}

One possible argument is that the level of bank concentration proxies for the degree of competition in the banking industry. According to this market power view, powerful banks (either directly or through policymakers) restrict competition, which boosts bank profits, lowers incentives for risk taking, and thus reduces systemic risk. Thus, the finding of a negative relationship between banking system concentration and systemic crises is consistent with the 
view that banking sector concentration increases banking system stability by reducing the openness and competitive of the banking industry.

In contrast to this market power explanation of how concentration promotes banking system stability, however, note that concentration remains negatively associated with crises even when controlling for regulatory restrictions on bank activities and measures of the openness and competitiveness of the banking industry and the economy more generally. Thus, to the extent that these variables adequately control for competition, the findings suggest that something else besides market power is driving the negative relationship between bank concentration and bank fragility.

The findings on bank regulations, banking freedom, economic freedom, and institutional development also run counter to the view that competition intensifies fragility. Restrictions on competition and openness -- such as regulatory impediments to the entry of new banks, or regulatory barriers to banks engaging in non-lending services, or general indicators of the openness of the banking industry or the overall economy - do not reduce the probability of suffering a systemic banking crisis (Table 4). Thus, the findings that (i) concentration lowers banking system fragility and (ii) low competition raises banking system fragility imply that concentration is not proxying for the degree of competition in the banking industry.

However, the measures of bank regulation, bank freedom, economic freedom, and institutional development may not sufficiently control for competition in banking. Thus, given the difficulty in adequately controlling for the competitive environment using regulatory indicators, some may view the Table 4 results as too weak to discard the market power explanation of why concentration is stabilizing. 


\section{B. Is it diversification?}

Next, consider the argument that banks in more concentrated banking systems are more diversified than banking systems composed of many small banks. If this argument is correct and if we include good measures of bank diversification in the systemic crises regressions, then this should drive out the significance of bank concentration.

To proxy for the diversification channel, we use three measures. First, we use Mean bank size, which equals total bank assets divided by the number of banks. ${ }^{14}$ The presumption is that larger banks tend to be more diversified. While clearly problematic, bank-level data on each bank's asset holdings are impossible to obtain. So, we use Mean bank size in trying to assess why concentration is associated with lower levels of banking system fragility. If mean bank size does not drive out the significance of concentration, this weakens the argument that concentrated banking systems have larger, better diversified banks than less concentrated banking systems with smaller banks. However, since bank size does not directly measure diversification, finding that mean bank size drives out concentration provides only suggestive support for the diversification argument.

Second, we include an indicator of regulatory restrictions on banks' ability to diversify risk abroad. Specifically, No foreign loans equals one if banks are prohibited from making foreign loans and zero otherwise. In many countries, it may be impossible for banks to sufficiently diversify their asset holding domestically. Thus, restrictions on investing abroad may doom domestic banks to holding excessively risky assets. Indeed, countries with both small banks and regulatory restrictions on those banks lending abroad may have especially unstable banks. Again, if we control for these measures of diversification and they drive out the significance of concentration in the systemic crisis regressions, then this provides "smoking gun"

\footnotetext{
${ }^{14}$ Using the mean bank size of the largest three banks does not change our results.
} 
evidence that concentration is associated with banking system stability because concentration is associated with more diversified banks.

A third potential indicator of bank diversification is the size of the economy. The presumption, albeit questionable, is that larger economies are more diversified and therefore offer banks easier means to hold diversified loan portfolios. Thus, we include the level of GDP in attempting to dissect the negative relationship between concentration and crises. ${ }^{15}$

The results in Table 6 provide suggestive support for the view that concentrated banking systems are composed of bigger, more diversified banks that are hence less prone to systemic failure. As the results in Table 6 show, the significance of the concentration coefficient drops to ten percent when we control for bank size and completely disappears when we control for the size of the economy (regressions 1 and 2). These findings are consistent with the view that part of the reason that concentration enhances stability is that concentrated systems are composed of bigger, better-diversified banks. Regression 3 indicates that including the No Foreign Loans does not alter the findings on banking system concentration. In regression 4 , the concentration effect becomes completely insignificant when including the (i) mean bank size, (ii) no foreign loans, and (iii) the interaction term between bank size and no foreign loans. This result in column 4 indicates that countries with larger banks become significantly more prone to systemic crises if they prohibit their banks from investing abroad. This finding on the interaction between bank size and regulatory restrictions on foreign loans runs counter to our prediction that restrictions on foreign lending would be particularly destabilizing for small (presumably less diversified) banks. Nevertheless, while these measures of diversification are highly imperfect, including these proxies for diversification drives out the significance of banking system concentration and suggests that the diversification explanation has some merit.

\footnotetext{
${ }^{15}$ Replacing GDP by M2 to control for the size of the financial system does not change our results.
} 


\section{Is it easier monitoring?}

A third argument for why concentration is stabilizing is that (i) concentrated banking systems tend to have a few large banks and (ii) a few large banks are easier to monitor than many small ones. As above, if this easier monitoring argument is correct and if we include good measures of monitoring in the crisis regressions, then this should drive out the significance of bank concentration. Of course, there are countervailing views. Large banks may be substantially more complex than small banks. So, supervision may be more difficult with a few, complex banks than with a higher number of simple banks. ${ }^{16}$

We use three measures to attempt to capture empirically the ease of monitoring banks. First, we use the No. of banks, which equals the number of banks in the economy. The easier monitoring argument relies on the presumption that concentrated banking systems have a few large banks and this is crucial in explaining better monitoring and greater banking system stability. Second, Activity Restrictions equals regulatory restrictions on the ability of banks to engage in securities market, insurance and real estate activities as well as restrictions on banks owning non-financial firms. The presumption is that greater regulatory restrictions will make it easier to monitor banks. So, to the extent that regulatory restrictions are correlated with bank concentration, this would help account for the negative relationship between concentration and systemic crises. Third, Cash-flow is the fraction of a bank's total cash-flow rights held by each bank's main owner, averaged across each country's banks. As suggested by La Porta et al (1999, 2002), countries where laws and regulations are ineffective at protecting the rights of small

\footnotetext{
${ }^{16}$ As pointed out to us by Mark Carey and Rene Stulz, there is another dimension to this monitoring argument. If monitoring skills are scare and there are economies of scope in monitoring, then concentrated banking systems may facilitate monitoring. However, the scarcity of monitoring skills, and hence the benefits of concentration, may different across countries.
} 
shareholders will tend to have corporations that do not rely on small shareholders to exert corporate control and instead have concentrated cash-flow rights to induce the main owner to exert sound corporate governance. In terms of banks, Caprio, Laeven, and Levine (2004) show that a bank's major owner tends to have higher cash-flow rights in countries where the institutions underlying monitoring of banks are weak, such as weak shareholder protection laws or ineffective bank supervision and regulation. These weak institutions discourage diffuse ownership and produce concentrated ownership of banks. Thus, we use each country's average cash-flow rights across banks as an additional proxy of each country's monitoring regime. If including cash-flow rights eliminates the significance of concentration, concerns would naturally arise about the endogeneity of cash-flow rights. But, if including cash-flow rights does not alter the results on concentration, then this simply represents an additional, if flawed, robustness check.

The results presented in Table 6 do not provide support for the easier monitoring view of why concentration reduces the likelihood of suffering a systemic crisis. Including the No. of banks, reduces the significance of Concentration to ten percent, but the significance level is restored once we also control for Activity Restrictions. Including Cash-flows does not alter the findings on Concentration either. No. of banks and Activity Restrictions do not enter the crises regressions significantly. Cash-flow enters positively, which is consistent with the view that in countries with weak legal and corporate governance institutions and ineffective bank supervision and regulation the ownership structure adjusts such that cash-flow becomes concentrated in order to boost monitoring incentives. However, the resultant outcome is still associated with a higher likelihood of suffering a crisis. For the purposes of this paper, the point is that including proxies for the monitoring regime does not alter the results on Concentration significantly. This 
suggests, to the extent that these are reasonable proxies, that Concentration is not a simple proxy for easier monitoring.

\section{Conclusions}

To summarize, using a cross-country, time-series panel of data on systemic banking crises, we find that greater bank concentration is associated with a lower likelihood of suffering a crisis. We never find that concentration increases fragility. While subject to the qualifications stressed in the Introduction and throughout the paper, the negative relationship between concentration and crises is robust to including various control variables, including indicators of the macroeconomic environment, the international environment, the domestic banking environment, bank supervisory and regulatory policies, and indexes of overall economic freedom and institutional development. Furthermore, reverse causality does not seem to be driving the concentration-stability findings. Thus, the data on systemic crises are more consistent with the concentration-stability view than with the concentration-fragility view.

In searching for the mechanisms underlying the concentration-stability result, we find no support for the view that banking system concentration is a proxy for a less competitive banking environment. We draw this conclusion for two reasons. First, when we include regulatory and institutional measures of the degree of competition in banking and the overall economy, we find that crises are less - not more - likely in competitive regulatory and institutional environments. Second, even when we control for these regulatory and institutional measure of the degree of competition, we continue to find that concentration is negatively associated with systemic crises. To the extent that we have good measures of the competitive environment, these findings suggest 
that banking system concentration is a proxy for something else besides banking industry competition.

Furthermore, we find suggestive support that concentrated banking systems have more diversified banks, but not evidence that concentrated banking systems with a few large banks are easier to monitor and hence more stable than less concentrated banking systems. On monitoring, none of our measures of the ease of monitoring enters significantly and including them in the analyses did not alter the coefficient on bank concentration. On diversification, the data indicate

that part of the reason concentrated banking systems lower the probability of suffering a systemic crisis is that concentrated banking systems tend to have larger, better-diversified banks with a correspondingly lower probability of failure. We draw this tentative conclusion because the concentration-crisis link weakens appreciably when we include proxies for diversification. We emphasize, however, that these proxies are aggregate indicators and do not directly measure individual bank asset diversification, and hence we view these results as suggestive and hope that they stimulate cross-country, bank-level research into this important policy issue.

\section{References}

Allen, Franklin, 1990. "The Market for Information and the Origin of Financial Intermediation." Journal of Financial Intermediation 1, 3-30.

Allen, Franklin and Douglas Gale, 2000. Comparing Financial Systems. Cambridge and London: MIT press.

Allen, Franklin and Douglas Gale, 2003. "Competition and Financial Stability.” Journal of Money, Credit, and Banking 36 (3 Pt.2), 433-480.

Bank for International Settlement, 2001. "The Banking Industry in the Emerging Market Economies: Competition, Consolidation, and Systemic Stability”, BIS Paper 4. 
Barth, J. R., G. Caprio Jr. and R. Levine (2001a), "The Regulation and Supervision of Banks Around the World: A New Database", In: Brooking-Wharton Papers on Financial Services, Eds: Litan, R. E. and R. Herring, Washington, DC, Brookings Institution: 183250.

Barth, James R., Gerard Caprio Jr., and Ross Levine, 2001, "Banking Systems Around the Globe: Do Regulation and Ownership Affect Performance and Stability?” In: F. Mishkin (ed.), Financial Supervision and Regulation: What Works and What Doesn't, Chicago, IL: Chicago University Press, 31-88.

Barth, James R., Gerard Caprio Jr., and Ross Levine, 2004, "Bank Supervision and Regulation: What Works Best?” Journal of Financial Intermediation, 13: 205-248.

Barth, J. R., G. Caprio Jr. and R. Levine (2005), Rethinking Bank Supervision and Regulation: Until Angels Govern, Cambridge, UK: Cambridge University Press, forthcoming.

Beck, Thorsten; Demirgüç-Kunt, Asli; Levine, Ross, 2000, "A New Database on the Structure and Development of the Financial Sector" The World Bank Economic Review 14, 597605.

Beck, Thorsten; Demirgüç-Kunt, Asli; Levine, Ross, 2003. "Law, Endowments, and Finance". Journal of Financial Economics 70, 137-181.

Beck, Thorsten; Demirgüç-Kunt, Asli; Levine, Ross, 2004. "Bank Supervision and Corruption in Lending," mimeo, which is a revised and renamed version of "Bank Supervision and Corporate Finance," National Bureau of Economic Research, Working Paper Series, No. 9620 (April 2003).

Besanko, D. and Thakor, A.V., 1993. "Relationship Banking, Deposit Insurance and Bank Portfolio", in: Mayer, C. and Vives, X. (eds.): Capital Markets and Financial Intermediation, Cambridge, UK: Cambridge University Press, 292-318.

Boot, A.W. and Greenbaum, S., 1993. "Bank Regulation, Reputation, and Rents: Theory and Policy Implications", ", in: Mayer, C. and Vives, X. (eds.): Capital Markets and Financial Intermediation, Cambridge, UK: Cambridge University Press, 292-318.

Boyd, J.H., and De Nicolo, G., 2005. "The Theory of Bank Risk-Taking and Competition Revisited" Journal of Finance, forthcoming.

Boyd, J. H. and S. Graham, 1991. Investigating the Banking Consolidation Trend, Federal Reserve Bank of Minneapolis Quarterly Review, Spring, 1-15.

Boyd, J. H. and S. Graham (1998). "Consolidation in US Banking," in Y. Amihud and G. Miller (eds.), Bank Mergers and Acquisitions, Norwell, MA. Kluwer, pp. 113-135. 
Boyd John H., and David E. Runkle, 1993. "Size and Performance of Banking Firms: Testing the Predictions of Theory." Journal of Monetary Economics 31, 47-67.

Boyd John H., and Edward C. Prescott, 1986. "Financial Intermediary-Coalitions.” Journal of Economic Theory 38, 211-232.

Calomiris, Charles W., 2000. U.S. Bank Deregulation in Historical Perspective. Cambridge University Press.

Calomiris, Charles W., and Joseph R. Mason, 2000. "Causes of Bank Distress During the Great Depression”, National Bureau of Economic Research, Working Paper No. 7919, Cambridge, MA.

Caminal, Ramon and Matutes, Carmen, 2002. "Market Power and Banking Failures", International Journal of Industrial Organization 20, 1341-61.

Caprio, Gerard, Jr., and Daniela Klingebiel, 1999, "Episodes of Systematic and Borderline Financial Distress", mimeo, The World Bank.

Caprio, Gerard, Jr., Luc Laeven, and Ross Levine, 2003, "Governance and Bank Valuation" National Bureau of Economic Research, Working No. 10158, Cambridge, MA.

Caprio, Gerard, Jr., and Maria Soledad Martinez-Peria, 2000. “Avoiding Disaster: Policies to Reduce the Risk of Banking Crises." Discussion Paper. Egyptian Center for Economic Studies.

Carkovic, Maria and Ross Levine, 2002. "Finance and Growth: New Evidence and Policy Analyses for Chile," In Norman Loayza and Raimundo Soto, Editors, Economic Growth: Sources, Trends, and Cycles, Santiago, Chile: Central Bank of Chile, pp. 343-376.

Carletti, Elena and Hartmann, Philipp, 2003. "Competition and Stability: What's Special about Banking?", in Mizen, P (ed.): Monetary History, Exchange Rates and Financial Markets: Essays in Honor of Charles Goodhart, Edward Elgar.

Chan, Yuk-Shee, Stuart Greenbaum, and Anjan Thakor, 1992. "Is Fairly Priced Deposit Insurance Possible?” Journal of Finance 47, 227-245.

Chong, Beng Soon, 1991. 'Effects of Interstate Banking on Commercial Banks' Risk and Profitability", Review of Economics and Statistics 73, 78-84.

Claessens, Stijn, Demirguc-Kunt, Asli and Harry Huizinga, 2001. "How Does Foreign Entry Affect Domestic Banking Markets?” Journal of Banking and Finance, 25(5), 891-911.

Cole, R. A. and Gunther, J.W., 1995. "Separating the Likelihood and Timing of Bank Failure." Journal of Banking and Finance 19(6), 1073-89. 
Cordella, T. and Yeyati, E.L., 2002. "Financial Opening, Deposit Insurance, and Risk in a Model of Banking Competition”, European Economic Review 46, 471-485.

Demirgüç-Kunt, Asli, 1989. "Deposit-Institution Failures: A Review of Empirical Literature," Economic Review, Federal Reserve Bank of Cleveland, Vol. 25, No.4.

Demirgüç-Kunt, Asli, and Enrica Detragiache, 1998, "The Determinants of Banking Crises in Developing and Developed Countries”, IMF Staff Papers, 45 (1), pp. 81-109.

Demirgüç-Kunt, Asli, and Enrica Detragiache, 1999, "Financial Liberalization and Financial Fragility", in B. Pleskovic and J.E. Stiglitz (Eds.) Proceedings of the 1998 World Bank Conference on Development Economics, Washington, DC, The World Bank.

Demirgüç-Kunt, Asli, and Enrica Detragiache, 2002, "Does Deposit Insurance Increase Banking System Stability? An Empirical Investigation.” Journal of Monetary Economics, 49 (7), pp.1373-1406.

Demirgüç-Kunt, Asli, Laeven, Luc and Ross Levine, 2004, "Regulations, Market Structure, Institutions, and the Cost of Financial Intermediation." Journal of Money, Credit and Banking 36: 593-622.

De Nicoló, Gianni, 2000. "Size, Charter Value and Risk in Banking: An International Perspective." International Finance Discussion Paper \#689, Board of Governors of the Federal Reserve System.

De Nicoló, Gianni, Batholomew, Philip, Zaman, Jahanara, and Zephirin, Mary, 2003. "Bank Consolidation, Conglomeration and Internationalization: Trends and Implications for Financial Risk.” IMF Working Paper \#03/158.

Diamond, Douglas W., 1984. "Financial Intermediation and Delegated Monitoring." Economic Studies 51, 393-414.

Dick, Astrid, 2003. "Nationwide Branching and Its Impact on Market Structure, Quality and Bank Performance.” Journal of Business, forthcoming.

Easterly, William and Ross Levine. 1997, “Africa's growth tragedy: policies and ethnic divisions.” Quarterly Journal of Economics 112, 1203-1250.

Easterly, W., Levine, R. 2003. “Tropics, Germs, and Crops: How Endowments Influence Economic Development," Journal of Monetary Economics, 50, 3-39.

Flannery, Mark J., 1989. “Capital Regulation and Insured Banks' Choice of Individual Loan Default Risks.” Journal of Monetary Economics 24, 235-258. 
Gonzales-Hermosillo, B; C. Pazarbasioglu, and R. Billings, 1997. "Banking System Fragility: Likelihood Versus Timing of Failure - An Application to the Mexican Financial Crisis," IMF Staff Papers.

Group of Ten, 2001. Report on Consolidation in the Financial Sector, Bank for International Settlements: Basel, Switzerland.

Hellman, Thomas, Kevin Murdock, and Joseph E. Stiglitz, 2000, "Liberalization, moral hazard in banking and prudential regulation: Are capital controls enough?" American Economic Review 90(1), 147-165.

Hughes, Joseph P. and Mester, Loretta, 1998. "Bank Capitalization and Cost: Evidence of Scale Economies in Risk Management and Signaling", Review of Economics and Statistics 80, $314-25$.

International Monetary Fund, 2001. Financial Sector Consolidation in Emerging Markets, Chapter V, International Capital Market Report.

Jayaratne, Jith and Strahan, Philip, 1998."Entry Restrictions, Industry Evolution, and Dynamic Efficiency: Evidence From Commercial Banking." Journal of Law and Economics 41 $239-75$.

Kaminsky, Graciela, and Reinhart, Carmen, 1999. "The Twin Crises: The Causes of Banking and Balance of Payments Problems.” American Economic Review 89, 473-500.

Kane, Edward J., 1989. The S\&L Insurance Mess: How Did It Happen? Washington: Urban Institute Press.

Kaufman, D., Kraay, A., Lobaton, P.Z. 1999. “Governance Matters.” World Bank Policy Research Department Working Paper No. 2196.

Keeley, Michael C., 1990. "Deposit Insurance, Risk and Market Power in Banking”, American Economic Review 80, 1183-1200.

La Porta, R., Lopez-de-Silanes, F., Shleifer, A., Vishny, R.W., 1997. "Legal determinants of external finance." Journal of Finance 52, 1131-1150.

La Porta, R., Lopez-de-Silanes, F., Shleifer, A., Vishny, R.W., 1999. "The Quality of Government." Journal of Law, Economics, and Organization 15, 222-279.

La Porta, Rafael, Florencio Lopez-de-Silanes, Andrei Shleifer, 2002. "Government Ownership of Banks." Journal of Finance, 57(1), 265-301.

Lindgren, Carl-Johan, Gillian Garcia, and Matthew I. Saal, 1996, Bank Soundness and Macroeconomic Policy, (Washington: International Monetary Fund). 
Macey, J.R., O'Hara, M., 2003, “The corporate governance of banks,” FRBNY Economic Policy Review 9, 91-107.

Matutes, Carmen and Vives, Xavier, 1996. "Competition for Deposits, Fragility and Insurance", Journal of Financial Intermediation 5, 184-216.

Matutes, Carmen and Vives, Xavier, 2000. "Imperfect Competition, Risk Taking and regulation in Banking", European Economic Review 44, 184-216.

Merton, Robert C., 1977." An Analytic Derivation of the Cost of Deposit Insurance and Loan Guarantees: An Application of Modern Option Pricing Theory.” Journal of Banking and Finance 1, 3-11.

Mishkin, Frederic S., 1999. “Financial Consolidation: Dangers and Opportunities.” Journal of Banking and Finance 23, 675-691.

O'Hara, Maureen and Shaw, W., 1990. "Deposit Insurance and Wealth Effects: The Value of Being 'Too Big to Fail', Journal of Finance 45, 1587- 1600..

Ramakrishnan, Ram and Anjan V. Thakor, 1984. "Information Reliability and A Theory of Financial Intermediation.” Review of Economic Studies 51, 415-432.

Sharpe, William F., 1978. "Bank Capital Adequacy, Deposit Insurance and Security Values." Journal of Financial and Quantitative Analysis 13, 701-718.

Smith, B.D., 1984. "Private Information, Deposit Interest Rates, and the 'Stability' of the Banking System”, Journal of Monetary Economics 14, 293-317.

Stiglitz, Joseph E., 1972. "Some Aspects of the Pure Theory of Corporate Finance: Bankruptcies and Takeovers." Bell Journal of Economics 3, 458-82.

Stulz, R. and R. Williamson, 2003. "Culture, Openness, and Finance.” Journal of Financial Economics 70, 313-49.

Sutton, John. 1991. Sunk Costs and Market Structure. Cambridge, MA: MIT Press.

Sutton, John. 1998. Technology and Market Structure. Cambridge, MA: MIT Press.

Tirole, Jean. 1988. The Theory of Industrial Organization. Cambridge, MA: MIT Press.

Williamson, Stephen D., 1986. " Costly Monitoring, Financial Intermediation, and Equilibrium Credit Rationing.” Journal of Monetary Economics 18, 159-179. 


\section{Table 1. Bank Concentration and Competition and Banking Crises}

GDP per capita is in constant dollars, averaged over the entire sample period, 1980-97. Crisis period denotes the years in which each country experienced a systemic banking crisis and the duration of said crisis. Concentration is a measure of concentration in the banking industry, calculated as the fraction of assets held by the three largest banks in each country, averaged over 1988-97. Sources are in the data appendix.

\begin{tabular}{|c|c|c|c|}
\hline & GDP per capita & Crisis Period & Concentration \\
\hline Australia & 17913 & & 0.65 \\
\hline Austria & 25785 & & 0.75 \\
\hline Bahrain & 9398 & & 0.93 \\
\hline Belgium & 24442 & & 0.64 \\
\hline Benin & 362 & $(1988-90)$ & 1.00 \\
\hline Botswana & 2781 & & 0.94 \\
\hline Burundi & 186 & & 1.00 \\
\hline Cameroon & 790 & $(1987-93,1995-98)$ & 0.95 \\
\hline Canada & 18252 & & 0.58 \\
\hline Chile & 3048 & (1981-87) & 0.49 \\
\hline Colombia & 1802 & $(1982-85)$ & 0.49 \\
\hline Congo & 940 & & 1.00 \\
\hline Ivory Coast & 843 & $(1988-91)$ & 0.96 \\
\hline Cyprus & 9267 & & 0.88 \\
\hline Denmark & 31049 & & 0.78 \\
\hline $\begin{array}{l}\text { Dominican } \\
\text { Republic }\end{array}$ & 1426 & & 0.65 \\
\hline Ecuador & 1516 & (1995-97) & 0.40 \\
\hline Egypt & 905 & & 0.67 \\
\hline El Salvador & 1450 & (1989) & 0.84 \\
\hline Finland & 23304 & (1991-94) & 0.85 \\
\hline France & 24227 & & 0.44 \\
\hline Germany & 27883 & & 0.48 \\
\hline Ghana & 356 & (1982-89) & 0.89 \\
\hline Greece & 10202 & & 0.79 \\
\hline Guatemala & 1415 & & 0.37 \\
\hline Guyana & 653 & $(1993-95)$ & 1.00 \\
\hline Honduras & 694 & & 0.44 \\
\hline India & 313 & (1991-97) & 0.47 \\
\hline Indonesia & 761 & $(1992-97)$ & 0.44 \\
\hline
\end{tabular}




\begin{tabular}{|c|c|c|c|}
\hline & GDP per capita & Crisis Period & Concentration \\
\hline Ireland & 13419 & & 0.74 \\
\hline Israel & 13355 & $(1983-84)$ & 0.84 \\
\hline Italy & 17041 & (1990-95) & 0.35 \\
\hline Jamaica & 1539 & (1996-97) & 0.82 \\
\hline Japan & 35608 & (1992-97) & 0.24 \\
\hline Jordan & 1646 & (1989-90) & 0.92 \\
\hline Kenya & 336 & (1993) & 0.74 \\
\hline Korea & 6857 & (1997) & 0.31 \\
\hline Lesotho & 356 & & 1.00 \\
\hline Malaysia & 3197 & $(1985-88,1997)$ & 0.54 \\
\hline Mali & 260 & $(1987-89)$ & 0.91 \\
\hline Mauritius & 2724 & & 0.94 \\
\hline Mexico & 3240 & $(1982,1994-97)$ & 0.63 \\
\hline Nepal & 179 & (1988-97) & 0.90 \\
\hline Netherlands & 22976 & & 0.76 \\
\hline New Zealand & 15539 & & 0.77 \\
\hline Nigeria & 251 & (1991-95) & 0.83 \\
\hline Norway & 28843 & (1987-93) & 0.85 \\
\hline Panama & 2824 & (1988-89) & 0.42 \\
\hline $\begin{array}{l}\text { Papua New } \\
\text { Guinea }\end{array}$ & 1024 & (1989-97) & 0.87 \\
\hline Peru & 2458 & $(1983-90)$ & 0.69 \\
\hline Philippines & 1070 & $(1981-87)$ & 0.49 \\
\hline Portugal & 8904 & $(1986-89)$ & 0.46 \\
\hline Senegal & 562 & (1988-91) & 0.94 \\
\hline Sierra Leone & 260 & (1990-97) & 1.00 \\
\hline Singapore & 20079 & & 0.71 \\
\hline South Africa & 3680 & (1985) & 0.77 \\
\hline Sri Lanka & 588 & (1989-93) & 0.86 \\
\hline Swaziland & 1254 & (1995) & 0.95 \\
\hline Sweden & 24845 & (1990-93) & 0.89 \\
\hline Switzerland & 42658 & & 0.77 \\
\hline
\end{tabular}




\begin{tabular}{lrcc}
\hline & GDP per capita & Crisis Period & Concentration \\
\hline Thailand & 1886 & $(1983-87,1997)$ & 0.54 \\
Togo & 366 & & 1.00 \\
Tunisia & 1831 & & 0.63 \\
Turkey & 2451 & $(1982,1991,1994)$ & 0.45 \\
United Kingdom & 16883 & & 0.57 \\
United States & $2445 \varsigma$ & $(1980-92)$ & 0.19 \\
Uruguay & 5037 & $(1981-85)$ & 0.87 \\
Venezuela & 3558 & $(1993-97)$ & 0.52 \\
Zambia & 464 & & 0.84 \\
\hline
\end{tabular}



Table 2. Summary Statistics and Correlations

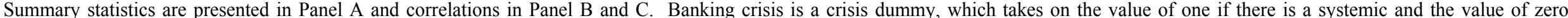

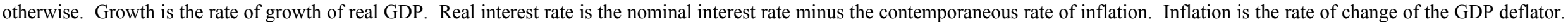

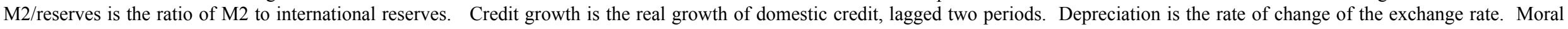

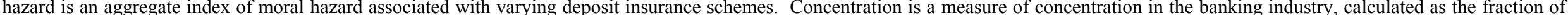

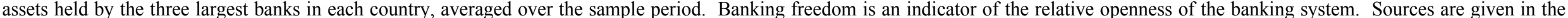
data appendix.

Panel A: Summary Statistics:

\begin{tabular}{|c|c|c|c|c|c|c|}
\hline & Mean & Median & St.Dev. & Maximum & Minimum & Observations \\
\hline Banking crisis & 0.04 & 0.00 & 0.20 & 1.00 & 0.00 & 1230 \\
\hline Real GDP Growth & 3.41 & 3.45 & 4.25 & 23.60 & -17.15 & 1216 \\
\hline Terms of trade change & 0.15 & 0.01 & 10.30 & 63.24 & -51.45 & 1191 \\
\hline Real interest rate & 1.58 & 2.68 & 19.34 & 151.21 & -283.00 & 1160 \\
\hline Inflation & 14.07 & 7.75 & 23.42 & 350.56 & -29.17 & 1220 \\
\hline M2/reserves & 19.87 & 6.56 & 68.86 & 1289.31 & 0.19 & 1222 \\
\hline Depreciation & 0.10 & 0.04 & 0.22 & 2.62 & -0.35 & 1238 \\
\hline Credit Growth $_{\mathrm{t}-2}$ & 6.01 & 5.09 & 15.84 & 115.42 & -54.62 & 1203 \\
\hline Real GDP per capita & 7813.94 & 2302.37 & 10299.92 & 45950.46 & 134.54 & 1222 \\
\hline Moral hazard & -1.09 & -2.49 & 2.24 & 3.98 & -2.49 & 1238 \\
\hline Concentration & 0.72 & 0.77 & 0.21 & 1.00 & 0.19 & 1106 \\
\hline Banking freedom & 3.36 & 3.00 & 0.88 & 5.00 & 1.00 & 1184 \\
\hline
\end{tabular}

Panel B: Correlations: Banking Crisis, Concentration, Macro Indicators, and Institutions

\begin{tabular}{|c|c|c|c|c|c|c|c|c|c|c|c|}
\hline & $\begin{array}{l}\text { Banking } \\
\text { Crisis }\end{array}$ & $\begin{array}{l}\text { Real GDP } \\
\text { growth }\end{array}$ & $\begin{array}{c}\text { Terms of } \\
\text { trade change }\end{array}$ & $\begin{array}{c}\text { Real interest } \\
\text { rate }\end{array}$ & Inflation & M2/reserves & Depreciation & $\begin{array}{c}\text { Credit } \\
\text { Growth }_{\text {t-2 }}\end{array}$ & $\begin{array}{l}\text { Real GDP } \\
\text { per capita }\end{array}$ & $\begin{array}{c}\text { Moral } \\
\text { Hazard }\end{array}$ & $\begin{array}{l}\text { Concentra- } \\
\text { tion }\end{array}$ \\
\hline Real GDP growth & $-0.158 * * *$ & 1.000 & & & & & & & & & \\
\hline Terms of trade change & -0.032 & 0.029 & 1.000 & & & & & & & & \\
\hline Real interest rate & $-0.079 * * *$ & $0.093 * * *$ & $-0.053 *$ & 1.000 & & & & & & & \\
\hline Inflation & $0.103 * * *$ & $-0.117 * * *$ & 0.043 & $-0.980 * * *$ & 1.000 & & & & & & \\
\hline M2/reserves & $0.094 * * *$ & $-0.117 * * *$ & 0.015 & 0.011 & -0.017 & 1.000 & & & & & \\
\hline Depreciation & $0.171 * * *$ & $-0.194 * * *$ & 0.002 & $-0.561 * * *$ & $0.642 * * *$ & -0.035 & 1.000 & & & & \\
\hline Credit Growth $_{\mathrm{t}-2}$ & -0.023 & 0.040 & 0.008 & 0.004 & -0.015 & $-0.097 * * *$ & $-0.103 * * *$ & 1.000 & & & \\
\hline Real GDP per capita & $-0.090 * * *$ & $-0.084 * * *$ & 0.015 & 0.029 & $-0.051^{*}$ & $-0.053^{*}$ & $-0.226 * * *$ & -0.014 & 1.000 & & \\
\hline Moral Hazard & $0.078 * * *$ & -0.004 & 0.030 & 0.028 & -0.037 & $-0.058 * *$ & $-0.096 * * *$ & -0.015 & $0.459 * * *$ & 1.000 & \\
\hline Concentration & $-0.062 * *$ & $-0.061 * *$ & -0.004 & 0.004 & -0.002 & $0.093 * * *$ & 0.040 & $-0.054 *$ & $-0.263 * * *$ & $-0.399 * * *$ & 1.000 \\
\hline Banking freedom & $0.183^{* * *}$ & 0.019 & -0.012 & 0.018 & -0.022 & $0.098 * * *$ & $0.070 * *$ & -0.020 & $-0.456 * * *$ & $-0.142 * * *$ & $0.257 * * *$ \\
\hline
\end{tabular}

$* * *, * *$, and $*$ indicate statistical significance at 1,5 , and 10 percent, respectively. 


\section{Table 3. Banking Crisis and Concentration}

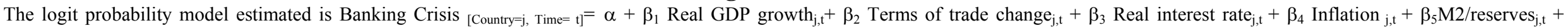

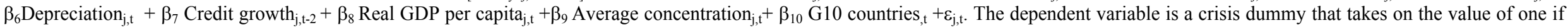

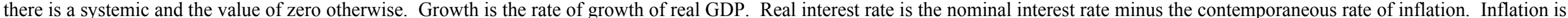

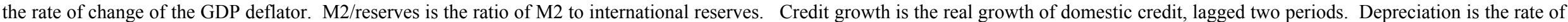

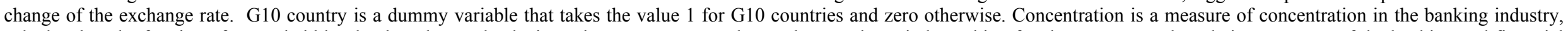

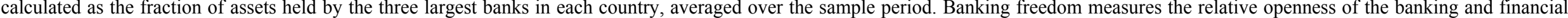

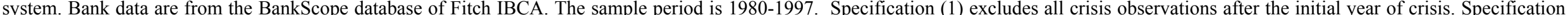

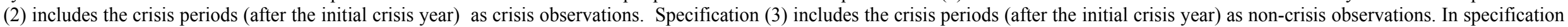

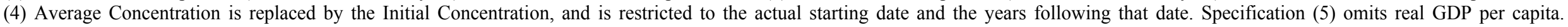

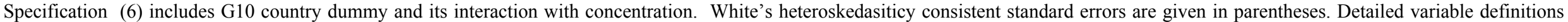
and sources are given in the data appendix.

\begin{tabular}{|c|c|c|c|c|c|c|}
\hline & (1) & (2) & (3) & (4) & (5) & (6) \\
\hline Real GDP growth & $\begin{array}{c}-0.163 * * * \\
(0.035)\end{array}$ & $\begin{array}{c}-0.088^{* * * *} \\
(0.020)\end{array}$ & $\begin{array}{c}-0.136^{* * * *} \\
(0.030)\end{array}$ & $\begin{array}{c}-0.306^{* * *} \\
(0.074)\end{array}$ & $\begin{array}{c}-0.164 * * * \\
(0.035)\end{array}$ & $\begin{array}{c}-0.164 * * * \\
(0.033)\end{array}$ \\
\hline $\begin{array}{l}\text { Terms of trade } \\
\text { change }\end{array}$ & $\begin{array}{l}-0.013 \\
(0.012)\end{array}$ & $\begin{array}{l}-0.008 \\
(0.007)\end{array}$ & $\begin{array}{l}-0.011 \\
(0.012)\end{array}$ & $\begin{array}{l}-0.034 \\
(0.024)\end{array}$ & $\begin{array}{l}-0.015 \\
(0.013)\end{array}$ & $\begin{array}{l}-0.012 \\
(0.012)\end{array}$ \\
\hline Real interest rate & $\begin{array}{c}0.010 * * * \\
(0.004)\end{array}$ & $\begin{array}{c}0.006 * * \\
(0.003)\end{array}$ & $\begin{array}{c}0.002 \\
(0.004)\end{array}$ & $\begin{array}{c}0.009 \\
(0.009)\end{array}$ & $\begin{array}{c}0.010 * * * \\
(0.004)\end{array}$ & $\begin{array}{c}0.010 * * * \\
(0.004)\end{array}$ \\
\hline Inflation & $\begin{array}{c}0.009 \\
(0.009)\end{array}$ & $\begin{array}{c}0.006^{* *} \\
(0.003)\end{array}$ & $\begin{array}{l}-0.002 \\
(0.005)\end{array}$ & $\begin{array}{l}-0.016 \\
(0.024)\end{array}$ & $\begin{array}{c}0.009 \\
(0.008)\end{array}$ & $\begin{array}{c}0.008 \\
(0.009)\end{array}$ \\
\hline M2/reserves & $\begin{array}{l}0.002^{*} \\
(0.001)\end{array}$ & $\begin{array}{c}0.002 * * \\
(0.001)\end{array}$ & $\begin{array}{c}0.001 \\
(0.001)\end{array}$ & $\begin{array}{c}0.001 \\
(0.002)\end{array}$ & $\begin{array}{l}0.002 * \\
(0.001)\end{array}$ & $\begin{array}{c}0.002 \\
(0.001)\end{array}$ \\
\hline Depreciation & $\begin{array}{c}0.453 \\
(1.142)\end{array}$ & $\begin{array}{c}0.624 \\
(0.425)\end{array}$ & $\begin{array}{c}0.706 \\
(0.991)\end{array}$ & $\begin{array}{l}1.802 \\
(2.696)\end{array}$ & $\begin{array}{c}0.777 \\
(1.133)\end{array}$ & $\begin{array}{c}0.491 \\
(1.151)\end{array}$ \\
\hline Credit Growth $_{\mathrm{t}-2}$ & $\begin{array}{l}0.014^{*} \\
(0.009)\end{array}$ & $\begin{array}{l}-0.001 \\
(0.005)\end{array}$ & $\begin{array}{c}0.012 \\
(0.009)\end{array}$ & $\begin{array}{c}0.028 * * * \\
(0.012)\end{array}$ & $\begin{array}{l}0.015^{*} \\
(0.009)\end{array}$ & $\begin{array}{c}0.014 \\
(0.009)\end{array}$ \\
\hline Real GDP per capita & $\begin{array}{l}-0.004 * \\
(0.002)\end{array}$ & $\begin{array}{c}-0.000 * * * \\
(0.000)\end{array}$ & $\begin{array}{l}-0.000^{*} \\
(0.000)\end{array}$ & $\begin{array}{c}-0.006^{*} \\
(0.004\end{array}$ & & $\begin{array}{l}-0.002 \\
(0.002)\end{array}$ \\
\hline Concentration & $\begin{array}{c}-1.946^{* * *} \\
(0.797)\end{array}$ & $\begin{array}{c}-1.479 * * * \\
(0.415)\end{array}$ & $\begin{array}{c}-1.696^{* *} \\
(0.747)\end{array}$ & $\begin{array}{c}-3.744 * * * \\
(1.430)\end{array}$ & $\begin{array}{c}-1.607 * * \\
(0.805)\end{array}$ & $\begin{array}{c}-1.845 * * * \\
(0.797)\end{array}$ \\
\hline G10 countries & & & & & & $\begin{array}{c}1.011 \\
(2.332)\end{array}$ \\
\hline $\begin{array}{l}\text { G10 countries } x \\
\text { concentration }\end{array}$ & & & & & & $\begin{array}{l}-3.287 \\
(5.091)\end{array}$ \\
\hline No. of Crises & 47 & 202 & 47 & 20 & 47 & 47 \\
\hline No. of Observations & 989 & 1144 & 1144 & 410 & 989 & 989 \\
\hline$\%$ crises correct & 68 & 57 & 64 & 70 & 68 & 70 \\
\hline$\%$ correct & 73 & 66 & 67 & 76 & 72 & 72 \\
\hline Model $\chi^{2}$ & $47.83 * * *$ & $75 * * *$ & $37.37 * * *$ & $40.34 * * *$ & $38.19 * * *$ & $46.38 * * *$ \\
\hline
\end{tabular}

***,**, and * indicate statistical significance at 1,5 , and 10 percent, respectively. 
Table 4. Banking Crisis, Regulation and Concentration

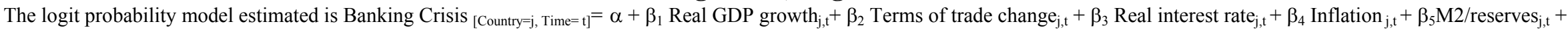

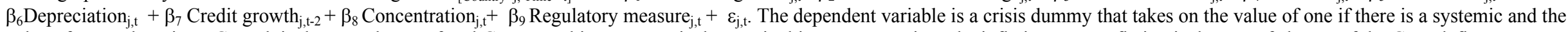
value of zero otherwise. Growth is the growth rate of real GDP. Real interest rate is the nominal interest rate minus the inflation rate. Inflation is the rate of change of the GDP deflator.

M2/reserves is the ratio of M2 to international reserves. Credit growth is the real growth of domestic credit, lagged two periods. Depreciation is the rate of change of the exchange rate.

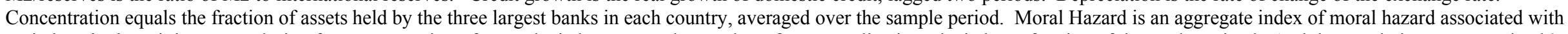

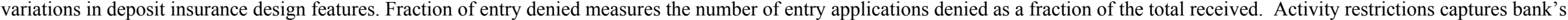

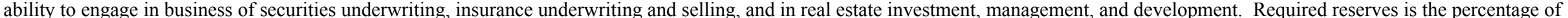

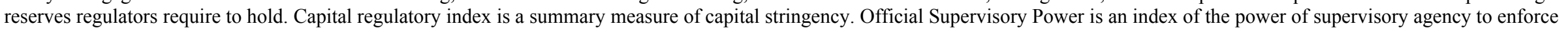

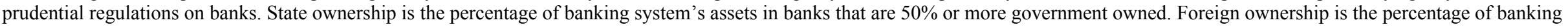

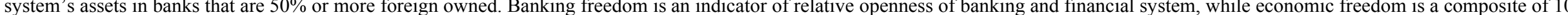

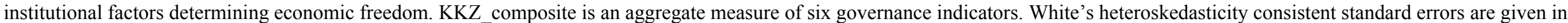
parentheses. Detailed variable definitions and sources are given in the data appendix. The sample period is 1980-1997.

\begin{tabular}{|c|c|c|c|c|c|c|c|c|c|c|c|}
\hline & (1) & (2) & (3) & (4) & (5) & (6) & (7) & (8) & (9) & (10) & (11) \\
\hline Concentration & $\begin{array}{c}-1.467 * * \\
(0.565)\end{array}$ & $\begin{array}{c}-2.556^{*} \\
(1.552)\end{array}$ & $\begin{array}{c}-2.285^{* * *} \\
(0.939)\end{array}$ & $\begin{array}{c}-2.472 * * * \\
(1.060)\end{array}$ & $\begin{array}{c}-2.847 * * * \\
(1.142)\end{array}$ & $\begin{array}{c}-2.533 * * \\
(1.096)\end{array}$ & $\begin{array}{c}-2.796^{* * *} \\
(1.091)\end{array}$ & $\begin{array}{c}-2.524 * * * \\
(1.083)\end{array}$ & $\begin{array}{c}-1.953 * * * \\
(0.806)\end{array}$ & $\begin{array}{c}-1.930 * * * \\
(0.809)\end{array}$ & $\begin{array}{c}-1.881 * * * \\
(0.769)\end{array}$ \\
\hline Moral Hazard & $\begin{array}{c}0.037 \\
(0.075)\end{array}$ & & & & & & & & & & \\
\hline Fraction of Entry Denied & & $\begin{array}{c}1.885^{* * *} \\
(0.737)\end{array}$ & & & & & & & & & \\
\hline Activity Restrictions & & & $\begin{array}{c}0.166^{* *} \\
(0.072)\end{array}$ & & & & & & & & \\
\hline Official Supervisory & & & & -0.021 & & & & & & & \\
\hline Power & & & & $(0.166)$ & & & & & & & \\
\hline Required Reserves & & & & & $\begin{array}{c}0.016 \\
(0.016)\end{array}$ & & & & & & \\
\hline Capital Regulatory Index & & & & & & $\begin{array}{l}-0.079 \\
(0.129)\end{array}$ & & & & & \\
\hline State ownership & & & & & & & $\begin{array}{l}0.015^{*} \\
(0.008)\end{array}$ & & & & \\
\hline Foreign ownership & & & & & & & & $\begin{array}{l}-0.005 \\
(0.008)\end{array}$ & & & \\
\hline Banking freedom & & & & & & & & & $\begin{array}{c}-0.506^{* * *} \\
(0.165)\end{array}$ & & \\
\hline Economic freedom & & & & & & & & & & $\begin{array}{c}-0.513 * * * \\
(0.225)\end{array}$ & \\
\hline KKZ_composite & & & & & & & & & & & $\begin{array}{c}-0.439 * * \\
(0.201)\end{array}$ \\
\hline No. of Crises & 47 & 21 & 34 & 34 & 27 & 33 & 32 & 31 & 47 & 47 & 47 \\
\hline No. of Observations & 989 & 583 & 767 & 767 & 572 & 755 & 686 & 609 & 955 & 955 & 989 \\
\hline$\%$ crises correct & 66 & 62 & 68 & 62 & 63 & 61 & 66 & 68 & 68 & 66 & 68 \\
\hline$\%$ correct & 71 & 81 & 79 & 78 & 77 & 79 & 74 & 73 & 70 & 70 & 72 \\
\hline Model $\chi^{2}$ & $37.93 * * *$ & $29.34 * * *$ & $38.21 * * *$ & $38 * * *$ & $30.46^{* * *}$ & $37.62 * * *$ & $30.97 * * *$ & $34.15^{* * *}$ & $52.41 * * *$ & $47.58 * * *$ & $49.59 * * *$ \\
\hline
\end{tabular}

$* * *, * *$, and $*$ indicate statistical significance at 1,5 , and 10 percent, respectively. 
Table 5. Banking Crisis and Concentration: Cost of Crises

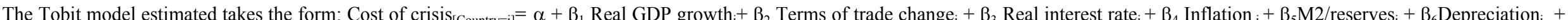

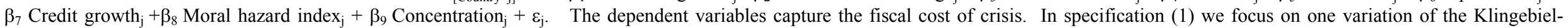

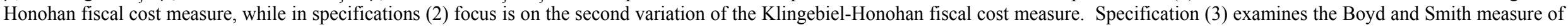

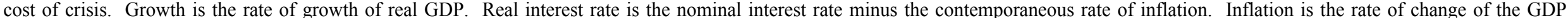

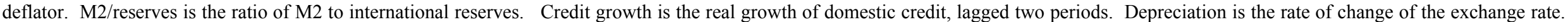

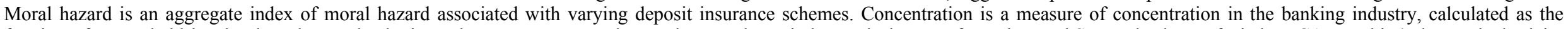

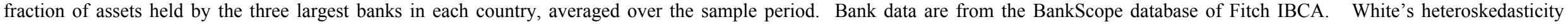
consistent standard errors are given in parentheses. Detailed variable definitions and sources are given in the data appendix.

\begin{tabular}{lccc}
\hline & $(1)$ & $(2)$ & $(3)$ \\
\hline Real GDP growth & $3.821^{* * *}$ & $3.614^{* * *}$ & $1.553^{* *}$ \\
Terms of trade change & $(0.811)$ & $(0.857)$ & $(0.814)$ \\
& $-0.929^{*}$ & -0.832 & 0.047 \\
Real interest rate & $(0.489)$ & $(0.593)$ & $(0.444)$ \\
& 0.235 & $0.591 * *$ & -0.139 \\
Inflation & $(0.191)$ & $(0.291)$ & $(0.257)$ \\
& $1.050^{* * *}$ & $1.198^{* * *}$ & 0.316 \\
M2/reserves & $(0.196)$ & $(0.272)$ & $(0.225)$ \\
& $0.144^{* * *}$ & $0.080^{* *}$ & $0.126^{* * *}$ \\
Depreciation & $(0.029)$ & $(0.036)$ & $(0.029)$ \\
& $-57.818^{* * *}$ & $-141.172^{* * *}$ & -26.592 \\
Credit Growth & $(16.742)$ & $(32.809)$ & $(21.046)$ \\
Real GDP per capita & 0.217 & 0.185 & 0.087 \\
& $(0.141)$ & $(0.155)$ & $(0.178)$ \\
Moral Hazard Index & $0.000^{* *}$ & 0.000 & -0.000 \\
& $(0.000)$ & $(0.000)$ & $(0.000)$ \\
& 0.408 & 0.764 & $1.343 *$ \\
Concentration & $(0.887)$ & $(0.912)$ & $(0.820)$ \\
& & & -2.269 \\
No. of obs. & -8.261 & $-15.006^{*}$ & $(9.355)$ \\
& $(7.499)$ & $(9.207)$ & \\
& & & 69 \\
\hline
\end{tabular}

***,**, and * indicate statistical significance at 1,5 , and 10 percent, respectively. 
Table 6. Banking Crisis and Concentration: Diversification vs. Ease of Supervision

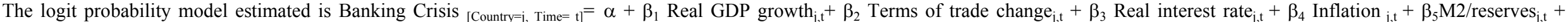

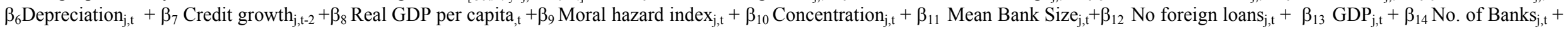

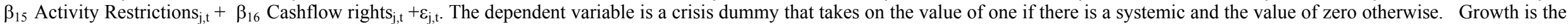

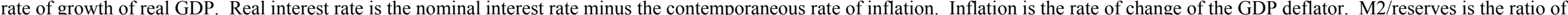

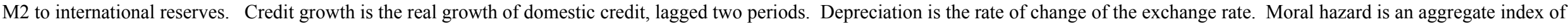

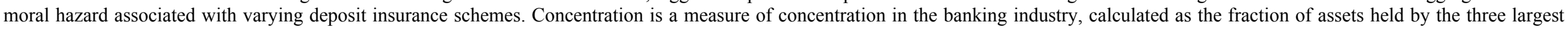

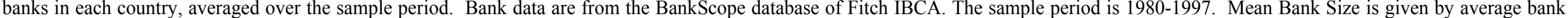

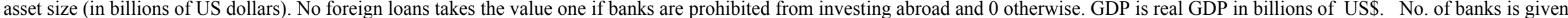

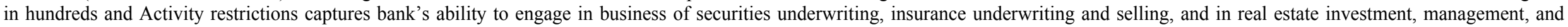

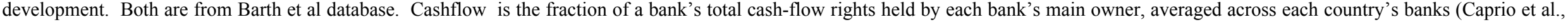
2004). White's heteroskedasticity consistent standard errors are given in parentheses. Detailed variable definitions and sources are given in the data appendix.

\begin{tabular}{|c|c|c|c|c|c|c|c|}
\hline & (1) & (2) & (3) & (4) & (5) & (6) & (7) \\
\hline Concentration & $\begin{array}{l}-1.511^{*} \\
(0.854)\end{array}$ & $\begin{array}{l}-1.379 \\
(0.860)\end{array}$ & $\begin{array}{c}-2.381^{* *} \\
(1.095)\end{array}$ & $\begin{array}{l}-1.653 \\
(1.119)\end{array}$ & $\begin{array}{l}-2.234^{*} \\
(1.162)\end{array}$ & $\begin{array}{c}-2.111^{* *} \\
(1.061)\end{array}$ & $\begin{array}{c}-3.576^{* *} \\
(1.651)\end{array}$ \\
\hline Mean Bank Size & $\begin{array}{c}0.004 \\
(0.005)\end{array}$ & & & $\begin{array}{c}0.007 \\
(0.005)\end{array}$ & & & \\
\hline No foreign Loans & & & $\begin{array}{c}0.153 \\
(0.635)\end{array}$ & $\begin{array}{l}-0.350 \\
(0.617)\end{array}$ & & & \\
\hline No foreign & & & & $0.184 * * *$ & & & \\
\hline Loans*Bank size & & & & $(0.068)$ & & & \\
\hline GDP (\$) & & $\begin{array}{c}0.0003 \\
(0.0002)\end{array}$ & & & & & \\
\hline No. of banks & & & & & $\begin{array}{c}0.008 \\
(0.014)\end{array}$ & $\begin{array}{c}0.003 \\
(0.013)\end{array}$ & \\
\hline Activity Restrictions & & & & & & $\begin{array}{c}0.141 \\
(0.103)\end{array}$ & \\
\hline Cashflow & & & & & & & $\begin{array}{c}0.030^{* *} \\
(0.014)\end{array}$ \\
\hline No. of Crises & 47 & 47 & 34 & 34 & 34 & 34 & 29 \\
\hline No. of obs. & 988 & 989 & 767 & 767 & 767 & 767 & 527 \\
\hline$\%$ crises correct & 68 & 72 & 65 & 62 & 62 & 68 & 72 \\
\hline$\%$ correct & 73 & 73 & 79 & 79 & 79 & 79 & 78 \\
\hline Model $\chi^{2}$ & $48.36^{* * *}$ & $48.79 * * *$ & $49.43 * * *$ & $43.90 * * *$ & $43.90 * * *$ & $43.43 * * *$ & $48.31 * * *$ \\
\hline
\end{tabular}

***,**, and $*$ indicate statistical significance at 1,5 , and 10 percent, respectively. 


\section{Data Appendix}

\begin{tabular}{|c|c|c|}
\hline Variable Name & Definition & Source \\
\hline Banking crisis & $\begin{array}{l}\text { Dummy takes on value of one during episodes identified as a } \\
\text { systematic banking crises }\end{array}$ & Demirguc-Kunt and Detragiache (2001) \\
\hline Real GDP Growth & Rate of growth of real GDP & WDI (World Bank) \\
\hline Terms of trade change & Change in the terms of trade & WDI (World Bank) \\
\hline Real interest rate & $\begin{array}{l}\text { Nominal interest rate minus the contemporaneous rate of } \\
\text { inflation }\end{array}$ & IFS (IMF) \\
\hline Inflation & Rate of change of GDP deflator & IFS (IMF) \\
\hline M2/reserves & Ratio of M2 to international reserves & IFS (IMF) \\
\hline Depreciation & Rate of depreciation & IFS (IMF) \\
\hline Credit growth & Rate of growth of real domestic credit to the private sector & IFS line $32 \mathrm{~d}$ divided by GDP deflator \\
\hline GDP/CAP & Real GDP per capita & WDI (World Bank) \\
\hline GDP & Real GDP in billions of US dollars & WDI (World Bank) \\
\hline Moral hazard index & $\begin{array}{l}\text { Principal component indicator measuring the generosity of } \\
\text { deposit insurance, based on co-insurance, coverage of foreign } \\
\text { currency and interbank deposits, type and source of funding, } \\
\text { management, membership and level of explicit coverage. }\end{array}$ & $\mathrm{DD}(2002)$ \\
\hline Concentration & $\begin{array}{l}\text { Degree of concentration in the banking industry, calculated as } \\
\text { the fraction of assets held by the three largest banks. Averaged } \\
\text { over the } 1988-97 \text { period. }\end{array}$ & Beck, Demirguc-Kunt, Levine (2000) - Financial Structures Database \\
\hline Initial Concentration & Initial degree of concentration in the banking industry. & BankScope database. \\
\hline Mean Bank Size & Total banking assets divided by number of banks. & BankScope database. \\
\hline No Foreign Loans & $\begin{array}{l}\text { Survey question } 7.2 \text { asks if banks are prohibited from making } \\
\text { loans abroad }(\text { yes }=1, \text { no }=0) .\end{array}$ & Barth, Caprio, and Levine (2001) - Survey of Bank Regulation and Supervision \\
\hline No. of Banks & No. of banks in hundreds. & Barth, Caprio, and Levine (2001) - Survey of Bank Regulation and Supervision \\
\hline Banking Freedom & $\begin{array}{l}\text { Indicator of relative openness of banking and financial system: } \\
\text { specifically, whether the foreign banks and financial services } \\
\text { firms are able to operate freely, how difficult it is to open } \\
\text { domestic banks and other financial services firms, how heavily } \\
\text { regulated the financial system is, the presence of state-owned } \\
\text { banks, whether the government influences allocation of credit, } \\
\text { and whether banks are free to provide customers with insurance } \\
\text { and invest in securities (and vice-versa). The index ranges in } \\
\text { value from } 1 \text { (very low - banks are primitive) to } 5 \text { (very high - } \\
\text { few restrictions). Averaged over 1995-97 period. }\end{array}$ & Index of Economic Freedom (Heritage Foundation) \\
\hline
\end{tabular}


Variable Name

Fraction of entry denied

Definition

Activity restrictions

Required reserves

Capital regulatory index

Official Supervisory Power

State ownership

Foreign ownership stringency.
Number of entry applications denied as a fraction of the number

of applications received from domestic and foreign entities

Indicator of bank's ability to engage in business of securities underwriting, insurance underwriting and selling, and in real estate investment, management, and development

\section{Ratio of reserves required to be held by banks}

Summary measure of capital stringency: sum of overall and initial capital stringency. Higher values indicate greater

Principal component indicator of 14 dummy variables: 1.Does the supervisory agency have the right to meet with external

auditors to discuss their report without the approval of the bank? 2.Are auditors required by law to communicate directly to the supervisory agency any presumed involvement of bank directors or senior managers in elicit activities, fraud, or insider abuse? 3.Can supervisors take legal action against external auditors for negligence? 4.Can the supervisory authority force a bank to change its internal organizational structure? 5.Are off-balance sheet items disclosed to supervisors? 6. Can the supervisory agency order the bank's directors or management to constitute provisions to cover actual or potential losses? 7. Can the supervisory agency suspend the directors' decision to distribute: a) Dividends? b) Bonuses? c) Management fees? 8.Can the supervisory agency legally declare-such that this declaration supersedes the rights of bank shareholders-that a bank is insolvent? 9.Does the Banking Law give authority to the supervisory agency to

intervene that is, suspend some or all ownership rights-a problem bank? 10.Regarding bank restructuring and reorganization, can the supervisory agency

or any other government agency do the following: a) Supersede shareholder rights? b) Remove and replace management? c)

Remove and replace directors?

Percentage of banking system's assets in banks that are $50 \%$ or more government owned

Percentage of banking system's assets in banks that are 50\% o more foreign owned
Source

Barth, Caprio, and Levine (2001) - Survey of bank Regulation and Supervision

Barth, Caprio, and Levine (2001) - Survey of bank Regulation and Supervision

Barth, Caprio, and Levine (2001) - Survey of Bank Regulation and Supervision Barth, Caprio, and Levine (2001) - Survey of Bank Regulation and Supervision

Barth, Caprio, and Levine (2001) - Survey of Bank Regulation and Supervision

Barth, Caprio, and Levine (2001) - Survey of Bank Regulation and Supervision

Barth, Caprio, and Levine (2001) - Survey of Bank Regulation and Supervision 
Economic Freedom

KK_composite

G10 countries

Growth GDP per capita
Composite of 10 institutional factors determining economic

freedom: trade policy, fiscal burden of government, government

intervention in the economy, monetary policy, capital flows and

foreign investment, banking and finance, wages and prices,

property rights, regulation, and black market activity. Individual

factors are weighted equally to determine overall score of

economic freedom. A high score signifies an institutional or

consistent set of policies that are most conducive to economic

freedom, while a score close to 1 signifies a set of policies that

are least conducive. Averaged over 1995-97 period.

Composite of six governance indicators (1998 data): voice and accountability, political stability, government effectiveness,

regulatory quality, rule of law, and corruption. Individual factors

are weighted equally to determine overall score of economic

freedom. Higher values correspond to better governance

outcomes.

Dummy accounting for G10 country

Rate of growth of real GDP per capita, averaged 1994-2001
Index of Economic Freedom (Heritage Foundation)

Kaufman and Kray (2000/1)

WDI (World Bank) 


\begin{tabular}{lll}
\hline Variable Name & Definition & Source \\
\hline Fee income & $\begin{array}{l}\text { Ratio of non-interest income to total bank assets, averaged 1994- } \\
\text { 2001. }\end{array}$ & Bankscope database \\
Total loan growth & Rate of growth of total loans, averaged 1994-2001. & Bankscope database \\
Standard dev of GDP per capita & Standard deviation of real GDP per capita & Calculated from real GDP per capita data taken from WDI (World Bank) \\
Growth GDP per capita & Rate of growth of real GDP per capita, averaged 1994-2001 & WDI (World Bank) \\
Inflation $^{\text {b }}$ & Rate of change of consumer price index, averaged 1994-2001 & IFS (IMF) \\
Concentration $^{\text {b }}$ & $\begin{array}{l}\text { Degree of concentration in the banking industry, calculated as the } \\
\text { fraction of assets held by the three largest banks. Averaged over } \\
\text { the 1994-2001 period. }\end{array}$ & Bankscope database \\
Banking Freedom $^{\text {b }}$ & $\begin{array}{l}\text { Indicator of relative openness of banking and financial system: } \\
\text { specifically, whether the foreign banks and financial services } \\
\text { firms are able to operate freely, how difficult it is to open } \\
\text { domestic banks and other financial services firms, how heavily } \\
\text { regulated the financial system is, the presence of state-owned } \\
\text { banks, whether the government influences allocation of credit, } \\
\text { and whether banks are free to provide customers with insurance } \\
\text { and invest in securities (and vice-versa). The index ranges in } \\
\text { value from 1 (very low - banks are primitive) to 5 (very high - } \\
\text { few restrictions). Averaged over 1994-2001 period. }\end{array}$ & \\
$\begin{array}{l}\text { Fraction of a bank's total cash-flow rights held by each bank's } \\
\text { main owner, averaged across each country's banks }\end{array}$ & Caprio, Laeven and Levine (2004) \\
\hline
\end{tabular}

